\title{
Function and dysfunction of plasma cells in intestine
}

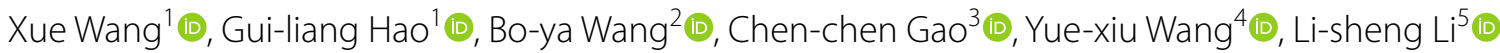 \\ and Jing-dong $\mathrm{Xu}^{3^{*}}$ (I)
}

\begin{abstract}
As the main player in humoral immunity, antibodies play indispensable roles in the body's immune system. Plasma cells (PCs), as antibody factories, are important contributors to humoral immunity. PCs, recognized by their unique marker CD138, are always discovered in the medullary cords of spleen and lymph nodes and in bone marrow and mucosal lymphoid tissue. This article will review the origin and differentiation of PCs, characteristics of short- and long-lived PCs, and the secretion of antibodies, such as IgA, IgM, and IgG. PCs play a crucial role in the maintenance of intestinal homeostasis using immunomodulation though complex mechanisms. Clearly, PCs play functional roles in maintaining intestinal health, but more details are needed to fully understand all the other effects of intestinal PCs.
\end{abstract}

Keywords: Plasma cells, Antibody, Immunomodulation, Intestine, Inflammatory bowel disease, Food allergy, Tumors

\section{Core tip}

This manuscript has the following components. First, after describing the origin of plasma cells (PCs), it summarizes their general biological features and common functions. The second component reveals the characteristics of short-lived PCs (SLPCs) and long-lived PCs (LLPCs). Notably, we depict how LLPCs survive in bone marrow and why they could be a double-edged sword in the human body. Thirdly, we summarize the functions of PCs, especially their function in the intestine. Next, we address some relationship between PC disfunction and intestinal diseases. Last but not least, some novel viewpoints on the pathogenesis of inflammatory bowel disease (IBD) and the unique role of IgA in intestinal food allergies and tumors are also emphasized.

\section{Introduction}

The gastrointestinal mucosa contains numerous plasma cells (PCs) under normal condition. Immunocytochemical studies [1] have shown that most of these PCs contain

\footnotetext{
*Correspondence: xujingdong@163.com

${ }^{3}$ Department of Physiology and Pathophysiology, School of Basic Medical

Science, Capital Medical University, No. 10, Xitoutiao, Youanmenwai,

Fengtai District, Beijing 100069, China

Full list of author information is available at the end of the article
}

(and presumably produce) immunoglobulin A (IgA). Immunoglobulin $G$ and $M$ (IgG and IgM, respectively) can be detected in a few of these PCs. Tolerance in the intestinal immune system is required to inhibit immunity against commensal bacteria, as well as an array of dietary antigens. The microenvironment regulates PC survival in the small intestine [2]. Additionally, bacterial Toll-like receptor (TLR) ligands induce survival factors of PCs, such as a proliferation-inducing ligand from intestinal epithelial cells [3], lamina propria dendritic cells (LPDCs) [4], and mucosal neutrophils [5]. Bacterial exposure induces not only LP-PC survival but also the generation of specific IgA-secreting (IgA+) LP-PCs [6]. We found that the number of IgA+ PCs was substantially increased in other immune organs, such as Peyer's patches (PPs) [7], mesenteric lymph nodes [7-9] (MLNs), spleen [10], and bone marrow (BM) [11], from colony-transferred mice. IgA + B cells in the PPs, MLNs, and spleen are considered the origin of IgA+ LP-PCs [7]. However, the IgA+ cells detected in these organs after the colony transfer are also CD138+, indicating that they are already differentiated PCs. Numerous Ig molecules are secreted by PCs. With the background described above, it seems obvious that intestinal PCs play a unique supporting role in maintaining the balance of intestinal immunity, and they are more complex than initially thought. 
In this review, after briefly describing the origin of PCs, we summarize their general biologic features and common functions to survey the differences between PCs in the intestine and other tissues. Notably, we review how PCs participate in maintaining intestinal health or disorder with $\mathrm{PC}$ dysfunction. To further indicate the regulatory function of PCs in intestine, we review the latest progress concerning tumors that have been attributed to shortcomings of immunological surveillance and immunoregulation. The colonic immune system, created by the innate and the acquired immune systems in a coordinated manner, has unique adaptations to limit both microbial exposure and immune responses, ensuring a limited response to commensal organisms under normal conditions $[12,13]$. Any dysfunctions occurring in components of immune system can significantly disrupt colonic homeostasis.

Every B cell is specific to a single antigen, but each cell can produce several thousand matching antibodies per second [14]. This prolific production of antibodies is an integral part of the humoral immune response. Furthermore, some promising targets are emerging for the study and treatment of IBD or tumors. However, more findings unearth more puzzles, and many details of intestinal PCs and the mechanistic understanding for IBD and intestinal allergy remain obscure and are discussed in the manuscript.

\section{Occurrence of PCs}

In 1963, Max D. Cooper and others discovered that chicken bursa of Fabricius could produce antibodies when they were investigating immune defense mechanisms, opening the era of B cell and PC research. PCs, also called effector B cells, are antibody factories that can synthesize and secrete thousands of clone-specific antibody molecules per second. Therefore, they play a crucial role in the intestinal immune system and are required to inhibit immunity against commensal bacteria, as well as an array of dietary antigens. PCs are the fully differentiated cells of the B-cell lineage [15] under physiological or pathophysiological conditions. Human B cells, derived from pluripotent stem cells of fetal liver or BM through pre-B cells, immature B cells, and eventually differentiated mature $B$ cells, are transported to the lymph nodes or spleen via the blood circulation and exist in the lymphoid nodules of the lymph node cortex area, medullary cord of the medullary area, perisplenic region and acini lienalis.

Cytokines [interleukin (IL)-2, IL-6, and IL-10] and direct cell-to-cell contact between $\mathrm{T}$ and $\mathrm{B}$ cells play vital roles in B-cell differentiation to PCs. In the lymph nodes, naïve follicular B cells, located in B-cell follicles, are surrounded by T-cell zones. After encountering an exogenous antigen, $\mathrm{B}$ cells proliferate and migrate to the border of the T-cell zone or interfollicular region, in which they interact with antigen-specific CD4+ T cells to become fully activated.

Differentiation of $B$ cells into PCs is affected by external and internal factors. Activated B cells can express IL-6 receptors, which can induce the differentiation to PCs $[16,17]$. However, IL-6 alone cannot promote the differentiation to PCs [18]. IL-10 also functions to increase PCs. IL-10, originally identified as a TH2 helper T-cell product, can inhibit cytokine production by TH1 cells, but it induces PCs to secrete large amounts of IgG, IgA, and IgM $[19,20]$. Furthermore, the interactions between CD27, which belongs to the nerve growth factor receptor/tumor necrosis factor receptor (NGFR/TNFR) family [21], and CD27 ligand (CD70), which belongs to the TNF family [22], occur not only on activated memory B cells but also on $\mathrm{T}$ cells, especially activated CD41 CD45RO $T$ cells [23], thus enhancing Ig production by B cells [24, 25 and suggesting that the CD27/CD70 interaction is involved in the differentiation of CD27+ memory B cells into PCs. These cell-surface molecules promoting the differentiation of B cells cooperate with each other to complete the differentiation of B cells into PCs by complex signaling pathways.

Other activities within the cell promote the differentiation of B cells into PCs. Over the past two decades, a handful of master regulators of $\mathrm{PC}$ differentiation have been identified. These transcription factors include $B$ lymphocyte-induced maturation protein-1 (BLIMP-1), interferon regulatory factor 4 (IRF4), and X-box binding protein-1 (XBP-1) [26-32]. In 1994, Turner [33] identified BLIMP-1, a 98-kD protein containing five zinc finger new structures, which is involved in the deacetylation and methylation of histone. All PCs and a small group of germinal center (GC) B cells can express BLIMP-1, but it is noteworthy that BLIMP-1 cannot be expressed by naïve or activated $B$ cells. The differentiation process is accompanied by the expression of Blimp-1, indicating that Blimp-1 mainly may play a fatal role in the differentiation and development of B cells in the GCs. However, whether BLIMP-1 is involved in the differentiation of B cells into PCs is ambiguous. In 2003, Shapiro-Shelef et al. [34] summarized the experience of a previous investigation that failed to study BLIMP-1-deficient mice and then skillfully devised a prdm1 flox/floxCD19Cre/+ mouse. Using NP-FICOLL (TI-antigen) and NP-KLH (TD-antigen) to stimulate the mice, they found that antigen-specific amplification does not depend on BLIMP-1 [35], but the presence of short-lived PCs (SLPCs) and long-lived PCs (LLPCs) produced by germinal centers requires the participation of BLIMP-1. At the same time, intraperitoneal injection of tamoxifen to remove the $\operatorname{prdm} 1$ gene in 
the $\mathrm{BM}$ in vivo was used to observe the number of PCs, and the activation of $B$ cells with LPS was used to observe alteration of the CD138+ PC level in vitro, confirming that BLIMP-1 is required for PC maintenance.

Blimp-1 induces PC development through at least three gene expression programs. First, Blimp-1 blocks the hyperplastic procedure of $B$ cells, such as direct inhibition of $c$-myc [36]. Second, Blimp-1 can upregulate some genes that promote Ig secretion, such as Ig heavy and light chain genes, J chain, XBP-1, C/EBP homologous protein (CHOP), and HSP70. Finally, Blimp-1 downregulates other genes that play important roles in the formation of the germinal center and B-cell activation, such as Pax-5 [37], Bcl-6, activation-induced cytidine deaminase (AID), BCR signaling-related genes, CD72, and CXCR5. If any of the three gene expression programs is disrupted, disease may occur, such as autoimmune diseases [38-42]. Therefore, there is a tremendous need to study the mechanism of Blimp-1 in PCs differentiation.

Additionally, BLIMP-1 is affected by multiple regulatory pathways [43]. The B cell-specific coactivator OBF-1 was found to be a positive regulator of BLIMP-1 by means of OBF-1 knockout mice compared with the wildtype (WT) mice [44]. In BLIMP-1 activation, the extracellular signal-regulated MAP kinase/mitogen-activated protein kinase (ERK/MAPK) pathway was discovered to be another important pathway using conditional ERK2knockout mice [45]. Moreover, conditional v-Rel avian reticuloendotheliosis viral oncogene homolog A (RelA) knockout mice showed that the nuclear factor kappa $B$ (NF-kB) pathway is also significant in BLIMP-1 regulation [46]. Above all, BLIMP-1 can play an indispensable role in PCs differentiation.

IRF4, as essential for class switch transformation (CSR) and PC differentiation [47-49]. IRF4 appears to positively regulate BLIMP-1; without it, BLIMP-1-mediated PC differentiation does not proceed [49]. Moreover, IRF4 and STAT3 activate BLIMP-1 in the late GC/early PB stages of PCs differentiation [30]. However, in recent years, some contrasting research found that IRF4 is dispensable in B cells for GC development, while others demonstrated that it is indispensable in B cells for GC formation by RNA-Seq analysis in ex vivo-derived mice [26, 31]. Nevertheless, IRF4 is required for GC formation and differentiation into PCs; however, the exact role of IRF4 in $\mathrm{GC}$ formation and whether $\mathrm{B}$ or $\mathrm{T}$ cells are involved in the intrinsic mechanism remain obscure.

Meanwhile, XBP-1, a component of the unfolded protein response (UPR), also plays an indispensable role in the differentiation of PCs. Relieving endoplasmic reticulum (ER) stress is the main function of UPR [50]. The protein kinase RNA activated (PKR)-like ER kinase (PERK), activating transcription factor 6 (ATF6a), and inositol-requiring enzyme-1 (IRE1) activate a myriad of factors from chaperone proteins to protein trafficking proteins to calcium modulators and, if necessary, apoptosis proteins [51]. Upon antigen stimulation, B cells differentiate into antibody-secreting cells (ASCs), which requires expansion of the ER and XBP1. Moreover, normal and malignant ASCs are exquisitely sensitive to proteasome inhibitors, however the underlying mechanisms remain unclear. $\mathrm{CHOP}$, which mediates apoptosis in lots of cell types, expresses at high-level under ER stress. Unlike other cell types, chop $^{-1-}$ ASCs are slightly more sensitive to ER stressors and proteasome inhibitors, signifying tissue-specific roles for $\mathrm{CHOP}$ in differentiation and stress [52].

Likewise, as a transcription factor containing a bZIP domain, XBP-1 has been implicated as a required factor in the generation of ASCs over the last 20 years. XBP-1 is a component of the IRE1 branch of the UPR. IRE1 can yield active XBP-1 (XBP-1s) by splicing the transcript of XBP-1 [50]. A study using murine splenic cells revealed XBP-1 to be downstream of BLIMP-1 in the PC differentiation program [53]. Mice lacking XBP-1 showed lower serum Ig than WT mice [32]. Furthermore, XBP-1 was not required in initial IgM $\mu$ chain synthesis; nevertheless, a few days after activation, XBP-1 deficiency might result in a steep decrease in Ig production [54]. In contrast, XBP-1 had no effect on light chain synthesis [54]. Therefore, the need for XBP-1 has been demonstrated, and it is responsible for factors involved in the secretory machinery of these ASCs. Above all, XBP1 is essential for the differentiation of PCs. This differentiation requires not only the expression of XBP1 but also the spliced isoform XBP1s. XBP1 regulates PC differentiation independently via its known functions in the ER stress response [55]. there is abnormal expression of XBP1, IRF4 or Blimp1, all PC differentiation-related genes, there will be maladjustment because XBP1-deficient PCs will fail to colonize their long-lived niches in the $\mathrm{BM}$ and sustain antibody secretion.

\section{Characteristics of SLPCs and LLPCs}

The first contact of $B$ cells with an antigen leads to the formation of antibody-secreting PBs, which will live for less than 1 week in extrafollicular foci and result in a short antibody response-that is, primary immune responses generate short-lived proliferative PBs, producing a transient burst of antigen-specific antibodies. Nonetheless, most ASCs, including antibody-secreting PBs and PCs generated during the memory immune response, leave the follicles of secondary lymphoid tissues as PBs. The features of the ASCs influence the duration of the antibody response, in addition to the affinity and isotype of 
the antibody that is made, all of which comprise important characteristics of protective immunity.

Fragment crystallizable domain $(\mathrm{Fc})$ receptor $(\mathrm{FcR})$ associated chain-null mice $\left(\mathrm{FC}^{-/-}\right)$demonstrate a selective defect in the expression of FcRs on the cell surface and in the FcR-mediated signaling cascade [56], and surprisingly, $\mathrm{Fcy}^{-1-}$ mice preferentially develop SLPCs and fail to develop a GC response. These results show that $\mathrm{Fcr}^{-/-}$mice display class switching to IgG2a as well as IgG1 and produce significantly higher serum titers of specific antibody than WT mice. Furthermore, $\mathrm{Fc}^{-/-}$ DCs show a more mature phenotype and produce at least two-fold more IL-12 than WT DCs. IL-12 can induce the formation of PCs and B-cell heavy chain class switching to IgG1 and IgG2a. The switch to IgG2 is IFN-y dependent; however, it is not required for IFN- $\gamma$ to promote the differentiation to PCs and switch to IgG1 [57]. Although IL-12 promotes SLPCs, perhaps in synergy with CD40L [57], memory B cell differentiation occurs independently of IL-12 [58, 59]. Therefore, IL-12 produced by DCs seems to be highly influential in directing $B$ cells to differentiate into SLPCs. However, antibodies produced by SLPCs have not only a short lifespan but also a low affinity with antigens, which are easy to remove in autoimmune diseases. Thus, their characteristics bring convenience to treatment. However, the antibodies secreted by LLPCs have a long lifespan.

As mentioned above, during the secondary immune response, most of the ASCs generated leave the follicles of secondary lymphoid tissues as PBs. Although the human recombinant c-fragment of TT (rTT.C)-specific PBs expresses the corresponding chemokine receptors, CXCR3 and CXCR4, only at low levels, they migrate in response to chemokine (C-X-C motif) ligand 9 (CXCL9) and CXCL12. Attraction by CXCL9 and CXCL12 promotes the migration of recently generated CXCR $3^{\text {low }}$ / CXCR $4^{\text {low }} / \mathrm{CD} 95^{\text {intermediate }} \mathrm{MHC}$ class $\mathrm{II}^{\text {high }} \mathrm{PBs}$ into the $\mathrm{BM}$ or inflamed tissue [60-63]. The BM contains multiple microenvironmental niches that is appropriate for cellular proliferation, differentiation and survival [64-69]. Each niche seems to support specifically one or a few hematopoietic stem or precursor cells. In this way, the sizes of these populations are limited by the number of available niches $[65,70]$. Therefore, newly generated $\mathrm{CXCR} 3^{\text {low }} / \mathrm{CXCR} 4^{\text {low }} / \mathrm{CD} 95^{\text {intermediate }} \mathrm{MHC}$ class II ${ }^{\text {high }} \mathrm{PBs}$ apparently compete with resident $\mathrm{CXCR} 3^{\text {high }}$ / CXCR $4^{\text {high }} / \mathrm{CD}^{\text {low }}{ }^{\text {low }}$ MHC class II $^{\text {low }}$ PCs for survival niches. Some authors have proposed that resident PCs from the $\mathrm{BM}$ are activated during an immune response. Because their numbers are nearly equivalent to the newly generated PBs, it is also thought that the BM-resident PCs are expelled from survival niches by newly generated PBs [71]. For mice, after immunization, BM-resident PCs occur late and do not migrate toward CXCL12, although resident PCs express high amounts of CXCR4. Specific ASCs are also found in BM [72-74], mucosa-associated lymphoid tissues, chronically inflamed tissues [75], and, to a lesser extent, the red pulp of spleens [76], which are mature PCs with a potential lifespan of more than 18 months [71, 72, 77]. Therefore, in mice, PCs of the BM can survive for a long time, nearly up to the lifespan of the immune system [72, 77], and this phenomenon can be inferred indirectly to occur in humans [78]. However, an increasing number of investigations have suggested that PC survival is not cell autonomous but depends on signals provided by its living environment. Benner et al. discovered that the most potent PC survival factors identified thus far are a proliferation-inducing ligand (APRIL), IL-6, TNF- $\alpha$, stromal-derived factor- $1 \alpha$, and signals transduced via CD44 [79-82] (Fig. 1). Additionally, BM mesenchymal stem cells (MSCs) provide survival factors in the human BM microniche that support LLPC survival [83-86]. The survival mechanisms of the $\mathrm{BM}$ microniche are thought to be mediated by local paracrine MSC secretion of IL-6 and vascular endothelial growth factor (VEGF) [87-89]. Basophils can positively regulate PC Ig secretion by markedly increasing IL-6 [90]. Additionally, activated eosinophils can secrete some cytokines, including IL-6, APRIL and IL-10 [91]. BM PCs share a microniche with megakaryocytes that can produce large amounts of IL- 6 to support PC growth and survival [92].

Paracrine signals from a series of cytokine-secreting cells mediate PC survival as well as Ig secretion, and there are direct cell-cell interactions that play significant roles in this process. One of the interactions is the communication between CD28 and its ligands CD86 and CD80. CD28 is expressed on PCs [93], as CD28 ${ }^{-1-}$ mice have reductive serum Ig titers, and the reduction may be due to PC intrinsic signaling by CD28 and not to a deficiency in activating $\mathrm{T}$ cells [93]. Developing PCs and LLPCs of the BM express the surface marker CD93, while CD $93^{-/-}$mice exhibit impaired antibody production following immunization [94]. In additional, the latest investigation [95] has re-confirmed that PC survival effects in BM can occur via MSC-derived extracellular vesicles (EVs), such as exosomes and microvesicles (MVs). EVs, which released from various cell types that have features distinguished by tetraspanins on their membrane surface, such as CD9, CD63, and CD81. The proteomic assessment of EVs has noted the significance of the PLC signaling pathway, including the presence of signaling proteins, specifically ras-like proto-oncoproteins A (RALA) and B (RALB). These proteins are both guanosine triphosphatases (GTPases) and act in close association with G-protein-coupled receptors (GPCR) to transduce 


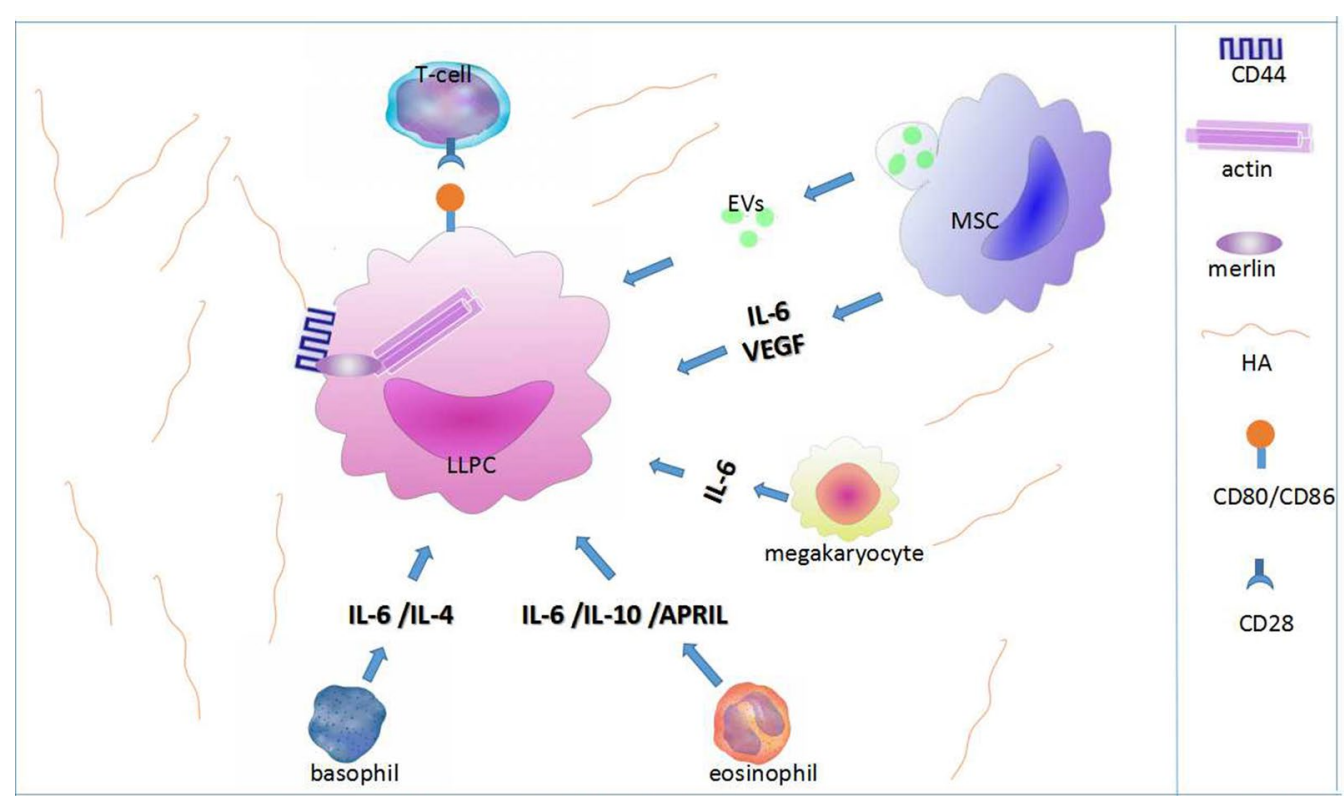

Fig. 1 Survival mechanism of LLPCs in bone marrow. IL-6 and VEGF from MSC secretion mediate the survival mechanisms of the PCs in BM. Beyond that, some of the LLPC survival effects in BM can occur via MSC-derived EVs, such as exosomes and MVs. Basophils can positively affect PC Ig secretion by secreting IL-6 and IL-4. Activated eosinophils secrete some cytokines, including APRIL, IL-6 and IL-10. Megakaryocytes support PC growth and survival by producing large amounts of IL-6. Communication between CD28 and its ligands CD86 and CD80 can sustain the survival of LLPCs [93]. When the number of PCs is reduced, the extracellular portion of CD44, a transmembrane glycoprotein, binds to the HA of the ECM, while the intracellular portion of CD44 binds to actin through the phosphorylation of merlin to form a growth-promoting transfer complex. MSC mesenchymal stem cells, HA hyaluronic acid, ECM extracellular matrix, merlin ERM family member [196]

signaling events via GTP hydrolysis; Moreover, RALA is required to suppress apoptosis [96]. Thus, EVs, which derived from BM-MSC secretions, can enhance survival of human ASC and provide a new field to explore PCs survival in BM.

LLPCs have been proposed in humans to explain the persistence, in the absence of antigen-specific stimulation, of antimicrobial antibodies with very long half-lives that have high affinity to and can provide protection against previously encountered pathogens. These LLPCs are important for maintaining protective antibody memory. However, this typical of a feature is also a doubleedged sword because autoimmune diseases are related to the differentiation and imbalance of LLPCs and SLPCs. So autoantibody-secreting LLPCs are refractory to conventional immunosuppressive therapy and represent a therapeutic challenge in autoimmune diseases [96-98].

\section{Function of PCs}

\section{Antibody secretion}

PCs, as white blood cells, can synthesize, integrate, and secrete large volumes of antibodies. Igs, essential molecules for a successful immune response to pathogens, can allow the immune system to recognize a myriad of pathogens and respond to them effectively [99]. Before exposure to antigen, a diverse antibody repertoire is generated early in the development of B cells through the successful rearrangement of the $\mathrm{D}, \mathrm{V}$, and $\mathrm{J}$ gene segments to create B cells. Each gene segment produces a particular Ig heavy- or light chain variable $(\mathrm{V})$ region [99]. The light chain and heavy chain genes of Ig undergo recombination, leading to the specificity for a unique antigen [100].

Upon encountering antigen and subsequent activation, determined by the nature of the antigen, some activation of $\mathrm{B}$ cells occurs with the assistance of $\mathrm{CD} 4+\mathrm{TH}$ cells [T-dependent activation (TD)] and without the assistance of TH cells [T-independent activation (TI)] [101]. Subsequently, B cells can not only differentiate into SLPCs but also enter GCs and differentiate into either LLPCs or memory B cells [101].

GCs are significant in Igs regulation because they are the location of somatic hypermutation (SHM), which can produce high-affinity antibodies, and one of the sites of class switch recombination (CSR), which change the functions of produced antibodies [102, 103]. SHM and CSR are largely targeted to the Ig genes. Regarding SHM, the mutations are mainly single-base substitutions, with occasional insertions and deletions. Although mutations occur throughout the rearranged $\mathrm{V}$ regions, 
there is preferential targeting to some hot spots which are WRCY (W=A or T, R=A or $\mathrm{G}, \mathrm{C}, \mathrm{Y}=\mathrm{T}$ or $\mathrm{C})$ and $\mathrm{WA}$, suggesting that there are higher-order structures or other local sequences which may also affect the mutations targets [104, 105]. In CSR, the $\mathrm{C} \mu$ region in naïve $\mathrm{B}$-cell Ig genes is replaced by downstream $\mathrm{C} \gamma, \mathrm{C} \varepsilon$ or $\mathrm{C} \alpha$ segments to generate IgG, IgE and IgA, respectively, which is mediated by an intrachromosomal recombinational event from the switch $(S)$ region in the $C \mu$ region $(\mathrm{C} \mu)$ to one of the downstream $\mathrm{S}$ regions. There are many molecules involved in SHM and CSR, such as AID, uracil DNA glycosylase (UNG), mismatch repair (MMR), errorprone DNA polymerases, and nonhomologous end joining (NHEJ). Although some of the enzymes involved have been identified in the last few years, some of the mutational factors have yet to be discovered, and there is still much to be learned regarding how they are coordinated and targeted to the $\mathrm{S}$ and $\mathrm{V}$ regions.

\section{Immune regulation}

Follicular helper $\mathrm{T}$ (TFH) cells have emerged as a new class of immune-regulatory cells specialized to control the stepwise development of antigen-specific B-cell immunity [106-108]. Within the 1st week after priming, antigen-specific TFH cells emerge to initiate antibody secretion [109-111], and GC reaction [112]. In the GC, TFH cells regulate memory B cell development [113115] and the production of LLPCs [116]. Upon antigen re-challenge, TFH cells promote antigen-specific memory B-cell expansion and the rapid induction of highaffinity PCs $[110,117]$. That is, the antigen-specific TFH function is central to multiple facets of B-cell immunity and the formation of LLPCs. Traditionally, the only role of PCs was thought to be antibody secretion [117]. In contrast, a recent study showed that conventional PCs could inhibit the development of TFH cells [118]. By immunizing C56BL/6 mice lacking Blimp-1 in the B-cell compartment to conduct experiments, it was found that the elevation of TFH cells in the absence of PCs provided support for the existence of a negative regulatory loop in vivo. Memory B cells develop in the absence of PCs [119], while their capacity for long-term immune protection is limited in the absence of PCs. IL-21, produced by TFH cells, is central to affinity maturation, GC persistence and function, and B-cell fate determination [119]. Thus, in the absence of PCs, it could be predicted that an increased number of GC TFH cells might result in elevated IL-21 production that could alter normal GC physiology and memory B-cell development and its function. By contrast, constraining the TFH numbers and reducing IL-21 production may progressively increase competitive pressure critical for GC survival signals. In this manner, it might be predicted that the negative regulation of GC
TFH function could enhance affinity maturation within the GC and promote memory B cells with higher overall affinities [118]. Therefore, a negative regulatory loop would act as an antigen-specific PC-sensing mechanism to limit the accelerated and explosive PC production that accompanies antigen re-challenge. However, a new point of view has been proposed, namely, that the process of TFH cell development that is primed by LLPCs or DCs participates in the upregulation of surface CD40L, whose downstream signaling pathway is necessary for the function of TFH cells [120]. T cells, primed with DCs or LLPCs, but not with SLPCs, can provide CD40L signals to B cells. Consistent with this, only CD4+ T cells primed with DCs or LLPCs, but not those primed with SLPCs, helped cognate B cells to differentiate to ASCs [121]. Regarding the molecular mechanisms underlying the action of LLPCs, it can be suggested that their effect on TFH polarization might be related to their reduced capacity to prime CD4+ T cells and their reduced IL-2 signaling, which inhibit TFH differentiation by inducing STAT5-dependent expression of Blimp-1, a repressor of BCL-6 [122-124].

\section{Function of PCs in the intestine}

\section{General characteristics of PCs in the intestine}

The gut acts as the entryway to many foreign antigens, including food components and potentially harmful pathogens. A first line of defense against these antigens is built by Igs, which can fight against pathogens or toxins [125], an innate barrier of mucus and antimicrobial peptides [126-128]. After the antigen enters the gastrointestinal tract and is combined with the microfold cell ( $M$ cell) membrane, the $M$ cell swallows the antigen and forms a pinocytotic vesicle. However, the antigen does not remain in the $\mathrm{M}$ cell lysosome; it is immediately transported to the basal membrane of the $\mathrm{M}$ cell and then is released into the epithelial lymphoid tissue [129]. There are abundant $\mathrm{T}$ and $\mathrm{B}$ lymphocytes in the lymphatic tissues of the gastrointestinal tract, but B lymphocytes are the majority [130]. Some of the activated B cells begin to proliferate and generate GCs within PPs or MLNs, which have been identified as locations of affinity maturation and probable isotype switching from IgM to IgA (Fig. 2). However, more investigations have demonstrated that the isotype switch of $\mathrm{B} 220+\mathrm{IgM}+$ cells, at least in part, occurs in the LP under the influence of local stimuli [131]. Most of the fully differentiated B cells leave MLNs and PPs and migrate via the lymphatics and thoracic duct into the blood, followed by transfer from blood circulation to the LP of the gut under the action of chemokines.

Lymphocytes from small intestinal lymph nodes return not only to the lamina propria and epithelial cells of the small intestine but also to the lamina propria and 

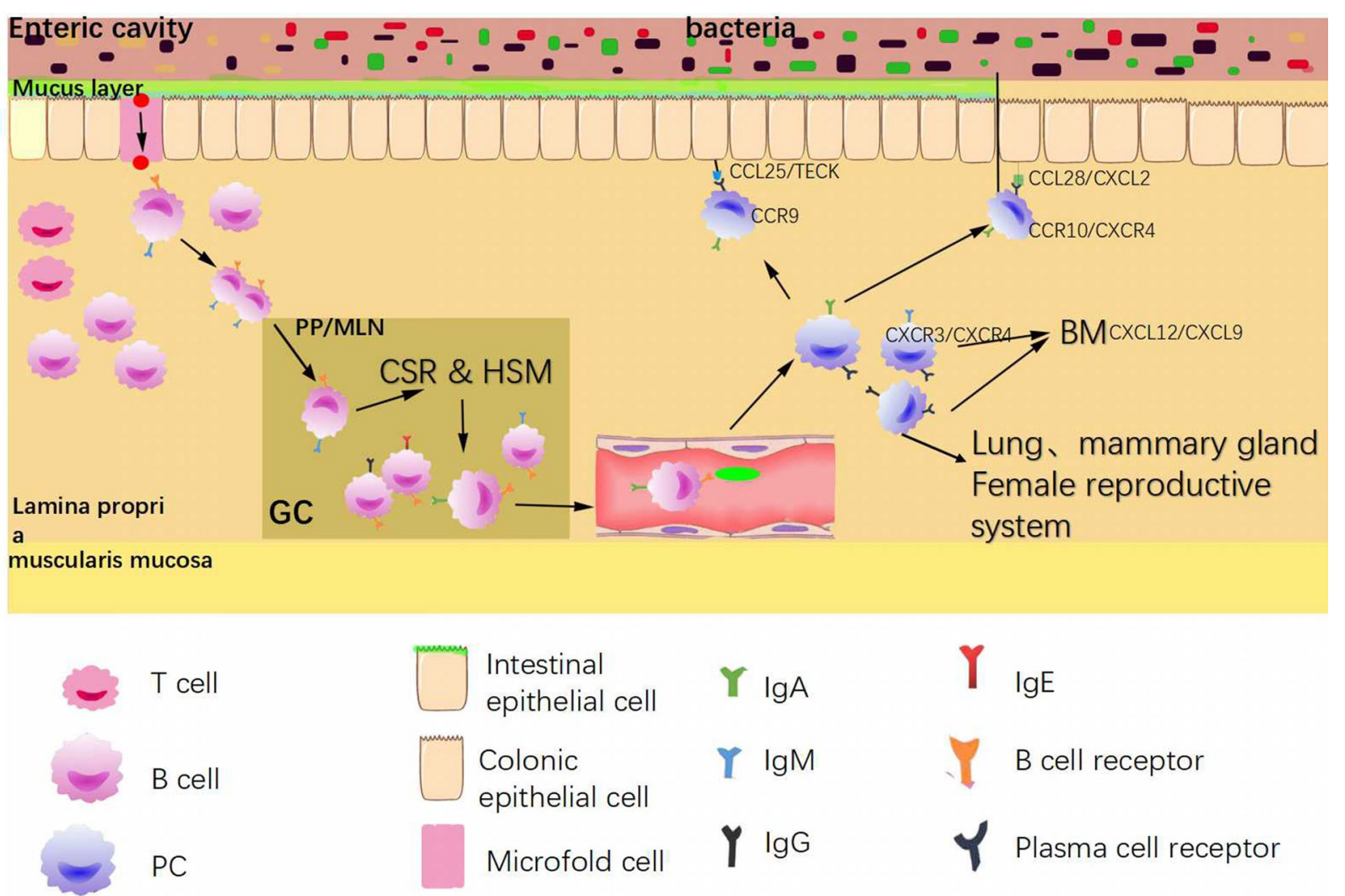

Fig. 2 An illustration of the working hypothesis of intestinal PC maturation and metastasis. T and B lymphocytes are abundant in the lymphatic tissues of the gastrointestinal tract. Some of the activated B cells begin to proliferate and generate GCs within PPs or MLNs, where affinity maturation and likely isotype switching from IgM to IgA occur. Most of the fully differentiated B cells leave PPs and MLNs and migrate to the blood. Next, under the action of chemokines, they transfer from the blood circulation to the LP of the small intestine. The IgA PCs express CCR9 and migrate to the small intestine [134], while the expression of CCR10/CXCR4 causes migration to the colon [133]. The IgM and IgG PCs that express CXCR3/CXCR4 migrate to the bone marrow. Lymphocytes from small intestinal lymph nodes return not only to the lamina propria and epithelial cells of the small intestine but also to the lamina propria and epithelial cells of the lungs, mammary gland, and female reproductive system, which is the common mucosal immune system (common mucosal immunologic system, CMIS)

epithelial cells of the lungs, mammary gland, and female reproductive system, which is the common mucosal immune system [132]. Based on this concept, the immune function of the intestinal tract can also cause the mucosal protection of other parts of the host, including the respiratory tract and female genital tract. However, because of the various intestinal antigens, will the production of various heterogeneous antibodies promote the occurrence of autoimmune diseases? This issue needs to be explored.

It is common knowledge that IgA ASCs in the mouse small intestine express CCR9, CCR10, and CXCR4 on the cell surface and migrate to their respective ligands CCL25, CCL28, and CXCL12 (also known as stromal cell-derived factor 1) [133] (Fig. 2), and it has been proposed that signaling through CCR9 might be an essential factor that targets cells to the intestine $[134,135]$. The CCR9 ligand CCL25/TECK is expressed by epithelial cells of the small intestine but not by those of the colon. However, IgA ASCs in the colon mainly express CCR10 and CXCR4 and migrate to CCL28 and CXCL12. Accordingly, the epithelial cells of the colon are positive for CCL28 and CXCL12 [133]. Murine IgA-producing PCs from the spleen, MLNs and PPs migrate toward CCL25 and CXCL12 [62, 136, 137]. Notably, PCs of the IgG or IgM isotype do not respond to CCL25 but migrate toward CXCL12 and CXCL9 [60, 62, 138], suggesting that the differential expression of chemokine receptors targets PCs to their final destination, depending on the isotype of the Igs.

\section{Production of the intestinal defender IgA by PCs}

The humoral immune response in the gastrointestinal tract is mediated by IgA+ memory B cells and IgA-producing PCs in gut-associated lymphoid tissue (GALT). Commensal bacteria, acting as critical stimuli, play a vital 


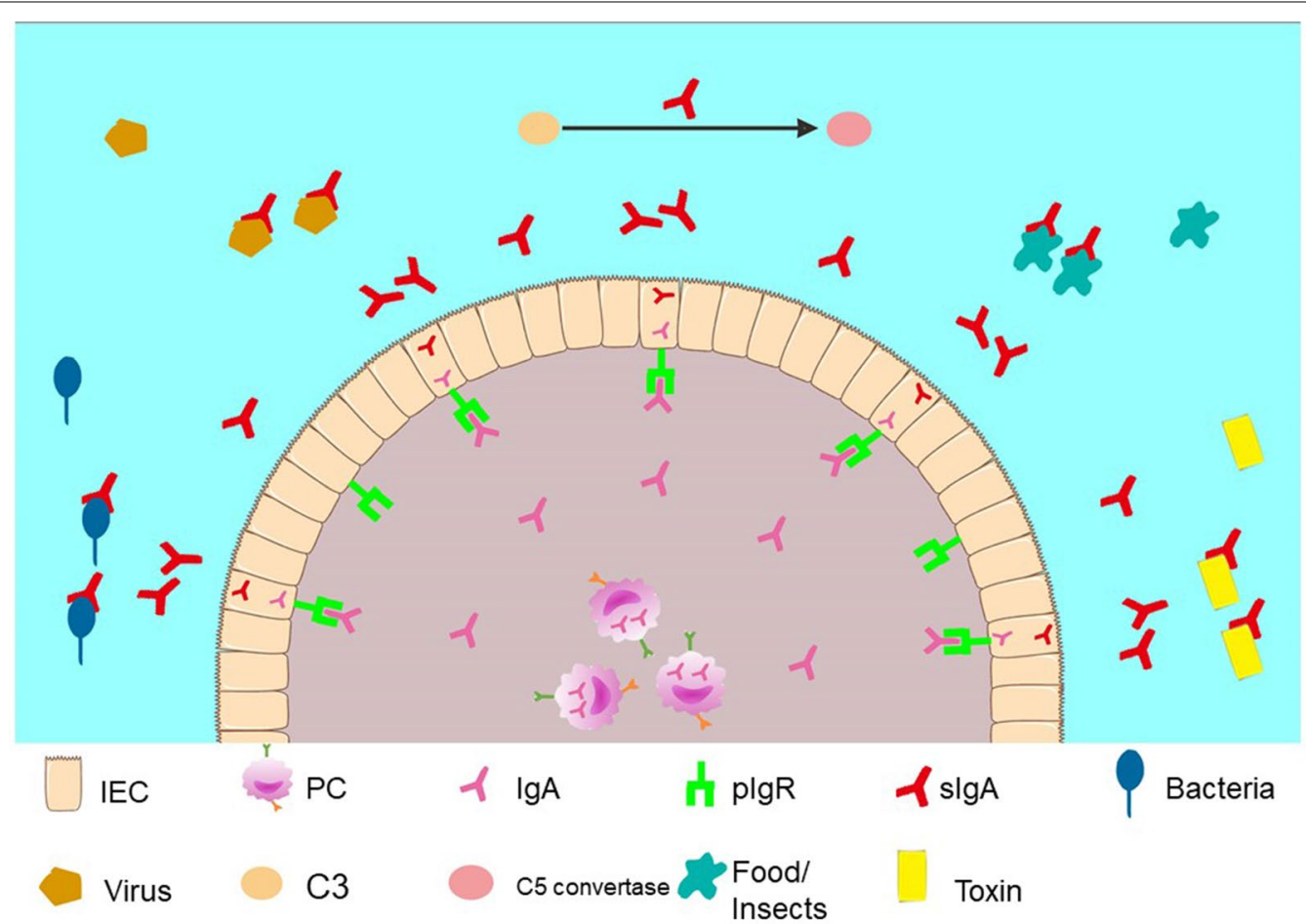

Fig. 3 Schematic representation of the function of intestinal slgA. slgA in the intestine can not only clear bacteria but also activate the C3 pathway to produce C5 convertase. Additionally, slgA neutralizes viruses both outside and inside susceptible cells [139, 141] by blocking food antigens and microbial antigens and neutralizing toxins

role in the maturation of GALT and further induce IgA production by B cells [138]. Class switching to IgA-producing PCs occurs in the PPs and lamina propria, following T-cell-dependent or T-cell-independent mechanisms [139]. Under the stimulation of antigen, IgA-producing PCs then secrete IgA, which binds to polymeric immunoglobulin receptor (pIgR) in intestinal epithelial cells, and the complex is transported to the enteric cavity through intestinal epithelial cells to form secretory IgA (sIgA) accompanied by its immune function (Fig. 3). pIgR, as an IgA-specific receptor with fatal roles in the synthesis, transport and secretion of sIgA, can also protect sIgA from being digested by proteolytic enzymes in the intestine without activation of complement.

sIgA in the enteral cavity can not only inhibit the adsorption of bacteria on the mucosa to clear bacteria [140] but also activate the complement 3(C3) pathway. sIgA in the enteric cavity shows synergistic antibacterial action with complement/alexin and lysozyme [139]. Furthermore, sIgA can neutralize viruses which are outside susceptible cells [139] and viruses that have infected cells [141] (Fig. 3) to establish host-microbial relationships by modulating bacterial epitopes and regulating bacterial metabolism [142]. Although some studies have indicated that sIgA might be specific to individual components of the commensal microbiota [143-146], continuous generation of high-affinity responses against lots of exogenous antigens encountered daily could be complicated in practice. Instead, others have suggested that sIgA has poly-reaction with antibodies which neutralize multiple targets with low affinity to prevent humans from attack of multiple antigens with low "cost" [147-149].

\section{Regulation of intestinal IgA by multiple factors}

sIgA plays a stable role in the regulation of the intestine, while intestinal mucosal lymphocytes show moderate secretion of $\operatorname{sIgA}$. IFN- $\gamma$ and TNF- $\alpha$, secreted by gut Th1 cells, downregulate [150] the secretion of IgA, while IL-4, IL-5, IL-6 and IL-10, as well as other cytokines produced by Th 2 cells, could induce and enhance secretory component gene expression of IgA. IL-4 is a vital inducer of IgA PCs. IL-5 can increase the response of IgA [151]. Particularly, IL- 6 plays a critical role in the orientation, proliferation and differentiation of IgA-secreting PCs at the mucosal effector point [152].

Probiotic bacteria can stimulate systemic and mucosal IgA production in humans [153, 154]. Probiotic bacteria can induce transforming growth factor (TGF)- $\beta$, IL-10, and IL-6 expression by mucosal epithelial cells, which potentiate IgA production through B-cell maturation and 
Table 1 Relationship between PCs, antibodies and intestinal diseases

\begin{tabular}{|c|c|c|}
\hline IBD & Change in IBD patients & References \\
\hline$B$ cells, $\lg A+$ and $\lg G+P C s$ & Increased in lesions of IBD patients & $\begin{array}{l}\text { MacDermott et al. [164] } \\
\text { Brandtzaeg et al. [165]; Con- } \\
\text { lon and Bird [172] }\end{array}$ \\
\hline Mucosal lgG4, serum lgG4 levels serum lgG4/lgG ratios & Increased in IBD patients & $\begin{array}{l}\text { Wang et al. [166] } \\
\text { Wang et al. [167] }\end{array}$ \\
\hline Intestinal food allergies & Intestinal mucosa status & References \\
\hline Decreased slgA & Hypersensitivity & $\begin{array}{l}\text { Telemo et al. [178] } \\
\text { Lilja et al. [177] } \\
\text { Thang et al. [179] }\end{array}$ \\
\hline Increased lgE & Hypersensitivity & $\begin{array}{l}\text { Galli et al. [180] } \\
\text { Burton et al. [181] }\end{array}$ \\
\hline Intestinal tumors & Impact on tumors & References \\
\hline Infiltration of B cells in intestine & Progression & Berntsson et al. [182] \\
\hline Lack of IgA in intestine & Decreased tumor-specific cytotoxicity & $\begin{array}{l}\text { Le Gouvello et al. [194] } \\
\text { Tosolini et al. [195] }\end{array}$ \\
\hline
\end{tabular}

class switching to IgA $[155,156]$. In the process of probiotic-induced intestinal mucosal immune responses, the upregulation of sIgA is based on the following process. First, antigenic substances such as probiotic metabolites or whole cells can enter the PPs through M cells and activate Th 2 cells. Next, with the assistance of IL-5 released by CD4+ Th2 cells, IgM+ B cells on PPs convert to IgA+ $B$ cells accompanied by the enhancement of the metabolic product of probiotics with the help of IL- 5 released by CD $4+$ Th 2 cells and cytokines such as TGF- $\beta$, IL-10, and IL-6.

\section{PC imbalance and intestinal diseases}

PCs play a crucial role in intestinal immune function, and their dysfunction or abnormal secretion of sIgA may often be accompanied by intestinal diseases (see Table 1).

\section{PCs and IBD}

Ulcerative colitis (UC) and Crohn's disease (CD) fall under idiopathic IBD [157]. UC has a relapsing and remitting course and is characterized by chronic inflammation of the rectum and colon $[158,159]$. Similarly, CD has a relapsing-remitting course, mostly occurring in the terminal ileum and right colon.

Circulating B cells have long been identified as CD3 CD19+ B cells [160], including IgD + CD27- naïve $\mathrm{B}$ cells, IgD $+\mathrm{CD} 27+$ non-class-switched memory $\mathrm{B}$ cells, and IgD-CD27+ class-switched memory B cells [24, 161]. Upon activation, naïve and memory B cells can differentiate to PCs, which produce antibodies. The numbers of PCs and PBs in UC patients are highly increased compared with those in healthy controls (HCs)
[161-163], at the same time B cells and IgA+ or IgG+ PCs are enhanced in the lesions of UC patients [164, 165]. The concentration of IgG, but not that of IgM or IgA, is notably higher in patients than in HCs [166]. Thus, IgG-producing PC infiltration of colonic mucosa leads to chronic inflammation in patients with UC. However, whether its function is pathogenic or protective remains mysterious. Michihide et al. [167] have demonstrated a novel aspect of UC pathogenesis in which unique IgG PCs infiltrate the inflamed mucosa via CXCR4 and critically influence UC pathogenesis by exacerbating mucosal inflammation through the activation of 'pathogenic' intestinal CD14 macrophages via IgG-IC Fc $\gamma \mathrm{R}$ signaling. Additionally, the concentration of serum IgG has been positively associated with the numbers of CD138+ $\mathrm{CD} 38+\mathrm{CD} 20-\mathrm{CD} 19+$ and IgG + CD38+ CD20CD19+ PBs in patients with UC. A case-control study by Wang found that patients with IBD had a dramatically higher mucosal IgG4 than healthy individuals, and in patients with UC, mucosal IgG4 was positively correlated with serum IgG4 level and serum IgG4/IgG ratio [168]. The characterization of these cells may provide a complementary approach to monitoring the disease activity or therapeutic efficacy in active UC patients, and high IgG4 level may be a biomarker for a new subset of IBD. Therefore, these discoveries perhaps provide a new method of controlling IBD by the specific inhibition of PCs that produce IgG antibodies. It will be worthwhile to explore further whether the precise attack on specific antibodies can reduce the side effects of immunosuppressive drugs in the treatment of the disease.

Of course, there is a novel viewpoint on the pathogenesis of IBD yet. Epidemiological surveys [169-171] 
have found that, with the improvement of people's living standards, the incidence of IBD has been increasing, and the incidence in the urban population is larger than that in the rural population. Some scientific research has suggested this phenomenon results from the improvement of living standards and changes in diet to foods with high energy density, animal proteins, total and saturated fats, sugar, and salt but low levels of plant-derived fibers. A "Western" diet may break the balanced composition of the gut microbiome, leading to perturbed immune responses, including effects on B-cell production, activation and maturation [171, 172]. Increased autoreactive and proinflammatory antibodies have been confirmed in obese humans and high-fat diet (HFD)-fed mice [173-175], The increased natural autoreactive IgM antibodies under an HFD form an immune complex with apoptosis inhibitors of macrophages, which promotes IgG autoantibody production contributing to the occurrence of IBD [176].

\section{PCs and intestinal food allergies}

Food allergies, as a type of immune-mediated reaction to ingested food proteins, have become a serious public health issue and harm the health of children and adults with increasing incidence yearly. In food allergic reactions, the intestinal mucosal immune system plays a momentous role in the process of identifying and removing pathogenic bacteria and inducing the body to form immune tolerance. sIgA on the surface of the mucosa recognizes certain antigen substances from food or air so that these antigens are dissociated from the surface of the mucosa and are not allowed to enter the body, thus avoiding the systemic immune response [177]. Oral tolerance is due to this function of sIgA [178]. Antibodies to food proteins appear in the serum of some patients, resulting in an increased incidence of hypersensitivity, which may be related to the lack of SIgA that weakens the ability to prevent the food antigens from invading the intestinal mucosa. Some studies of infants have shown that whey protein allergies are generally related to local IgA response defects and IgE-mediated hypersensitivity. Thang et al. [179] exposed $\beta$-globulin-sensitized mice to probiotics, and the results showed that the inhibition mechanism of the allergic reaction was the increase in sIgA in the intestinal tract, which prevented the invasion of food allergens in the intestinal mucosa to inhibit allergic reactions. The occurrence of intestinal food allergies is associated with a reduction in sIgA. Titers of high-affinity allergen-specific IgE antibodies are increased in patients with symptomatic allergy [180]. Allergen-specific IgE has also been suggested to lead to allergy pathogenesis by promoting antigen presentation and epitope spreading by the uptake of antigen-IgE complexes through low-affinity $\mathrm{CD} 23$, an IgE receptor, present on antigen-presenting cells (APCs) [181]. Thus, could increasing the contents of IgA and IgE on PCs in the local colon be a new strategy to treat irritable bowel disease? Does it cause immune dysfunction and autoimmune diseases? These problems are worthy of further exploration.

\section{PCs and intestinal tumors}

Colorectal cancer (CRC) is one of the most common tumor types worldwide. There are many risk factors that lead to CRC, and one of the most important factors is chronic intestinal inflammation. A prospective population-based cohort showed that B cell-specific CD20, $\mathrm{CD} 138$, and immunoglobulin kappa $\mathrm{C}$ expression correlated significantly with lower tumor stage it is also demonstrated that infiltration of B cells in CRC had a great impact on tumor progression and prognosis [182]. A recent study of immunized CRC patients showed that patients with higher IgA titers showed better survival, although the relationship was only significant in univariate regression analyses [183]. Several studies in vitro also indicated that IgA can mediate tumor-specific cytotoxicity through NK cells or polymorphonuclear phagocytes [183-186]. CCL28 signaling through CCR10, together with a4b7-MAdCAM-1 interactions, is a pivotal part of IgA-producing PB migration to intestinal sites, both in the steady state and during vaccine-induced immune responses [187-190]. However Muthuswamy et al. recently argued persuasively [191] that the endothelium in colon tumors expresses less MAdCAM-1 than the surrounding unaffected mucosa. More research has shown that CCL28 production is also reduced in colon tumors [192, 193]. The lower the IgA secretion is at the tumor site, the higher is the risk of bacterial penetration into the tissues leading to reduced local barrier function [194, 195]. Above all, IgA may reduce bacteria-induced inflammation at the tumor site, and a lack of IgA locally at the tumor site may lead to increased local inflammation and drive tumor progression.

\section{Conclusion}

To summarize the above arguments, PCs with their various antibodies act as warriors in humoral immunity. In healthy intestinal mucosa, PCs play an essential role in maintaining homeostasis by producing many antibodies, especially sIgA. As an intestinal defender, sIgA plays a stable role in the regulation of the gastrointestinal neuroendocrine-immune system network. Notably, once the regulation of IgA-secreting cells or sIgA is imbalanced, such as over- or under-activation, diseases such as IBD, intestinal food allergies, and tumors may generate. New findings concerning intestinal PCs and IBD, as well as tumors, can be very helpful for studies and disease 
treatments. Meanwhile, there are many details awaiting clarification, as well as many unresolved issues.

\begin{abstract}
Abbreviations
PCs: plasma cells; SLPCs: short-lived plasma cells; LLPCs: long-lived plasma cells; IBD: inflammatory bowel disease; TLR: toll-like receptor; LP-DCs: lamina propria dendritic cells; PPs: Peyer's patches; MLNs: mesenteric lymph nodes; BM: bone marrow; NGFR/TNFR: nerve growth factor receptor/tumor necrosis factor receptor; BLIMP-1: B lymphocyte-induced maturation protein-1; IRF4: interferon regulatory factor 4; XBP-1: X-box binding protein-1; GC: germinal center; ERK/MAPK: MAP kinase/mitogen-activated protein kinase; CSR: class switch transformation; PERK: (PKR)-like ER kinase; ATF6a: activating transcription factor 6; IRE1: inositol-requiring enzyme-1; APRIL: proliferation-inducing ligand; MSCs: mesenchymal stem cells; VEGF: vascular endothelial growth factor; GPCR: G-protein-coupled receptors; SHM: somatic hypermutation; TFH: follicular helper T; GALT: gut-associated lymphoid tissue; UC: ulcerative colitis; CD: Crohn's disease; HFD: high-fat diet; APCs: antigen-presenting cells; CRC: colorectal cancer.
\end{abstract}

\section{Authors' contributions}

$X W$ and $\mathrm{GH}$ contributed equally to the writing of this manuscript; XW and GH and JX wrote the manuscript; XW, GH and BW designed the illustrations; $L L$ and $Y W$ analyzed the data; JX revised the manuscript. All authors read and approved the final manuscript.

\section{Author details}

${ }^{1}$ School of Basic Medical Sciences, Xuanwu Hospital, Beijing Capital Medical University, Beijing 100069, China. ${ }^{2}$ Peking University Health Science Center, Beijing 100081, China. ${ }^{3}$ Department of Physiology and Pathophysiology, School of Basic Medical Science, Capital Medical University, No. 10, Xitoutiao, Youanmenwai, Fengtai District, Beijing 100069, China. ${ }^{4}$ Department of Teaching Office, International School, Capital Medical University, Beijing 100069, China. ${ }^{5}$ Function Platform Center, School of Basic Medical Science, Capital Medical University, Beijing 100069, China.

\section{Acknowledgements}

Not applicable.

\section{Competing interests}

The authors declare that they have no competing interests (including relevant financial interests, activities, relationships and/or affiliations).

\section{Availability of data and materials}

Not applicable.

\section{Consent for publication}

Not applicable.

\section{Ethics approval and consent to participate} Not applicable.

\section{Funding}

National Natural Science Foundation of China, No. 81673671, No. 81274173 and No. 81270443; Beijing National Science Foundation, No. 7122017.

\section{Publisher's Note}

Springer Nature remains neutral with regard to jurisdictional claims in published maps and institutional affiliations.

\section{Received: 30 January 2019 Accepted: 1 March 2019}

Published online: 13 March 2019

\section{References}

1. Taylor CR, Burns J. The demonstration of plasma cells and other immunoglobulin-containing cells in formalin-fixed, paraffin-embedded tissues using peroxidase-labelled antibody. J Clin Pathol. 1974;27:14-20.
2. Mesin L, Di Niro R, Thompson KM, Lundin KE, Sollid LM. Long-lived plasma cells from human small intestine biopsies secrete immunoglobulins for many weeks in vitro. J Immunol. 2011;187:2867-74. https ://doi.org/10.4049/jimmunol.1003181.

3. Xu Y, Zhao Y, Huang H, Chen G, Wu X, Wang Y, Chang W, Zhu Z, Feng Y, Wu D. Expression and function of toll-like receptors in multiple myeloma patients: toll-like receptor ligands promote multiple myeloma cell growth and survival via activation of nuclear factor-kappaB. Br J Haematol. 2010;150:543-53. https://doi.org/10.1111/j.1365-2141.2010.08284.

4. Varol C, Vallon-Eberhard A, Elinav E, AychekT, Shapira Y, Luche H, Fehling HJ, Hardt WD, Shakhar G, Jung S. Intestinal lamina propria dendritic cell subsets have different origin and functions. Immunity. 2009;31:502-12. https://doi.org/10.1016/j.immuni.2009.06.025.

5. Fournier BM, Parkos CA. The role of neutrophils during intestinal inflammation. Mucosal Immunol. 2012;5:354-66. https://doi.org/10.1038/ mi.2012.24.

6. Chen Y, Chaudhary N, Yang N, Granato A, Turner JA, Howard SL, Devereaux C, Zuo T, Shrestha A, Goel RR, Neuberg D, Wesemann DR. Microbial symbionts regulate the primary Ig repertoire. J Exp Med. 2018;215:1397-415. https://doi.org/10.1084/jem.20171761.

7. Gommerman JL, Rojas OL, Fritz JH. Re-thinking the functions of IgA(+) plasma cells. Gut Microbes. 2014;5:652-62. https://doi. org/10.4161/19490976.2014.969977.

8. von Vietinghoff SL, Ley K. IL-17A controls IL-17F production and maintains blood neutrophil counts in mice. J Immunol. 2009;183:865-73. https://doi.org/10.4049/jimmunol.0804080.

9. Antoine JC, Avrameas S, Gonatas NK, Stieber A, Gonatas JO. Plasma membrane and internalized immunoglobulins of lymph node cells studied with conjugates of antibody or its Fab fragments with horseradish peroxidase. J Cell Biol. 1974;63:12-23.

10. Boggs DR, Marsh JC, Chervenick PA, Cartwright GE, Wintrobe MM. Factors influencing hematopoietic spleen colony formation in irradiated mice. V. Effect of foreign plasma upon colony forming cell kinetics. J Cell Physiol. 1968;71:227-38. https://doi.org/10.1002/jcp.1040710305.

11. Jiang $D$, et al. The effect of adipose tissue derived MSCs delivered by a chemically defined carrier on full-thickness cutaneous wound healing. Biomaterials. 2013;34:2501-15. https://doi.org/10.1016/j.biomateria Is.2012.12.014.

12. Hooper LV, Macpherson AJ. Immune adaptations that maintain homeostasis with the intestinal microbiota. Nat Rev Immunol. 2010;10:159-69. https://doi.org/10.1038/nri2710.

13. Kinnebrew MA, Pamer EG. Innate immune signaling in defense against intestinal microbes. Immunol Rev. 2012;245:113-31. https://doi. org/10.1111/j.1600-065X.2011.01081.

14. Sutton LA, Agathangelidis A, Belessi C, Darzentas N, Davi F, Ghia P, Rosenquist R, Stamatopoulos K. Antigen selection in B-cell lymphomas - tracing the evidence. Semin Cancer Biol. 2013;23:399-409. https ://doi.org/10.1016/j.semcancer.2013.07.006.

15. Roth K, Oehme L, Zehentmeier S, Zhang Y, Niesner R, Hauser AE. Tracking plasma cell differentiation and survival. Cytometry A. 2014;85:15-24. https://doi.org/10.1002/cyto.a.22355.

16. Taga T, Kawanishi Y, Hardy RR, Hirano T, Kishimoto T. Receptors for B cell stimulatory factor 2. Quantitation, specificity, distribution, and regulation of their expression. J Exp Med. 1987;166:967-81.

17. Schaper F, Rose-John S. Interleukin-6: biology, signaling and strategies of blockade. Cytokine Growth Factor Rev. 2015;26:475-87. https://doi. org/10.1016/j.cytogfr.2015.07.004.

18. Splawski JB, McAnally LM, Lipsky PE. IL-2 dependence of the promotion of human B cell differentiation by IL-6 (BSF-2). J Immunol. 1990;144:562-9.

19. Rousset F, Garcia E, Defrance T, Peronne C, Vezzio N, Hsu DH, Kastelein $\mathrm{R}$, Moore KW, Banchereau J. Interleukin 10 is a potent growth and differentiation factor for activated human B lymphocytes. Proc Natl Acad Sci USA. 1992:89:1890-3.

20. Fluckiger AC, Garrone P, Durand I, Galizzi JP, Banchereau J. Interleukin 10 (IL-10) upregulates functional high affinity IL-2 receptors on normal and leukemic B lymphocytes. J Exp Med. 1993;178:1473-81.

21. Camerini D, Walz G, Loenen WA, Borst J, Seed B. The T cell activation antigen CD27 is a member of the nerve growth factor/tumor necrosis factor receptor gene family. J Immunol. 1991;147:3165-9. 
22. Goodwin RG, Alderson MR, Smith CA, Armitage RJ, VandenBos T, Jerzy R, Tough TW, Schoenborn MA, Davis-Smith T, Hennen K, Et A. Molecular and biological characterization of a ligand for CD27 defines a new family of cytokines with homology to tumor necrosis factor. Cell. 1993;73:447-56.

23. Agematsu K, Kobata T, Sugita K, Hirose T, Schlossman SF, Morimoto C. Direct cellular communications between CD45R0 and CD45RA T cell subsets via CD27/CD70. J Immumol. 1995;154:3627-35.

24. Agematsu K, et al. CD27: a memory B-cell marker. Immunol Today. 2000;21:204-6.

25. Kobata T, Jacquot S, Kozlowski S, Agematsu K, Schlossman SF, Morimoto C. CD27-CD70 interactions regulate B-cell activation by T cells. Proc Natl Acad Sci USA. 1995;92:11249-53.

26. Bollig N, Brustle A, Kellner K, et al. Transcription factor IRF4 determines germinal center formation through follicular T-helper cell differentiation. Proc Natl Acad Sci USA. 2012;109:8664-9. https://doi.org/10.1073/ pnas.1205834109.

27. Diehl SA, Schmidlin H, Nagasawa M, et al. STAT3-mediated up-regulation of BLIMP1 Is coordinated with BCL6 down-regulation to control human plasma cell differentiation. J Immunol. 2008;180:4805-15.

28. Ding BB, Bi E, Chen H, Yu JJ, Ye BH. IL-21 and CD40L synergistically promote plasma cell differentiation through upregulation of Blimp-1 in human B cells. J Immunol. 2013;190:1827-36. https://doi.org/10.4049/ jimmunol.1201678.

29. Saito M, Gao J, Basso K, et al. A signaling pathway mediating downregulation of BCL6 in germinal center $B$ cells is blocked by BCL6 gene alterations in B cell lymphoma. Cancer Cell. 2007;12:280-92. https://doi. org/10.1016/j.ccr.2007.08.011.

30. Kwon H, Thierry-Mieg D, Thierry-Mieg J, et al. Analysis of interleukin21-induced Prdm1 gene regulation reveals functional cooperation of STAT3 and IRF4 transcription factors. Immunity. 2009;31:941-52. https:// doi.org/10.1016/j.immuni.2009.10.008.

31. Willis SN, Good-Jacobson KL, Curtis J, et al. Transcription factor IRF4 regulates germinal center cell formation through a B cell-intrinsic mechanism. J Immunol. 2014;192:3200-6. https://doi.org/10.4049/ jimmunol.1303216.

32. Reimold AM, Iwakoshi NN, Manis J, et al. Plasma cell differentiation requires the transcription factor XBP-1. Nature. 2001;412:300-7. https:// doi.org/10.1038/35085509.

33. Bretz J, Garcia J, Huang X, et al. Noxa mediates p18INK4c cell-cycle control of homeostasis in B cells and plasma cell precursors. Blood. 2011:117:2179-88. https://doi.org/10.1182/blood-2010-06-288027.

34. Shapiro-Shelef M, Lin Kl, Savitsky D, Liao J, Calame K. Blimp-1 is required for maintenance of long-lived plasma cells in the bone marrow. J Exp Med. 2005;202:1471-6. https://doi.org/10.1084/jem.20051611.

35. Lin Y, Wong K, Calame K. Repression of c-myc transcription by Blimp-1, an inducer of terminal B cell differentiation. Science. 1997;276:596-9.

36. Lin Kl, Lin Y, Calame K. Repression of C-myc is necessary but not sufficient for terminal differentiation of B lymphocytes in vitro. Mol Cell Biol. 2000;20:8684-95.

37. Lin Kl, Angelin-Duclos C, Kuo TC, Calame K. Blimp-1-dependent repression of Pax- 5 is required for differentiation of $B$ cells to immunoglobulin M-secreting plasma cells. Mol Cell Biol. 2002;22:4771-8039.

38. Dehner C, Fine R, Kriegel MA. The microbiome in systemic autoimmune disease: mechanistic insights from recent studies. Curr Opin Rheumatol. 2019;31:201-7. https://doi.org/10.1097/BOR.0000000000000574.

39. Aaron L, Torsten M, Patricia W. Autoimmunity in celiac disease: extra-intestinal manifestations. Autoimmun Rev. 2019. https://doi. org/10.1016/j.autrev.2018.09.010.

40. Jorgensen SF, Fevang B, Aukrust P. Autoimmunity and inflammation in CVID: a possible crosstalk between immune activation, gut microbiota, and epigenetic modifications. J Clin Immunol. 2019;39:30-6. https:// doi.org/10.1007/s10875-018-0574-z.

41. Rojas $\mathrm{OL}$, et al. Recirculating intestinal lgA-producing cells regulate neuroinflammation via IL-10. Cell. 2019;176:610-24. https://doi. org/10.1016/j.cell.2018.11.035.

42. Brandtzaeg P. Review article: homing of mucosal immune cells-a possible connection between intestinal and articular inflammation. Aliment Pharmacol Therap. 1997;11:24-37.

43. YU YHLK. Factors that regulate the generation of antibody-secreting plasma cells. Adv Immunol. 2016;131:61-99.
44. Corcoran LM, Hasbold J, Dietrich W, et al. Differential requirement for OBF-1 during antibody-secreting cell differentiation. J Exp Med. 2005:201:1385-96. https://doi.org/10.1084/jem.20042325.

45. Yasuda T, Kometani K, Takahashi N, Imai Y, Aiba Y, Kurosaki T. ERKs induce expression of the transcriptional repressor Blimp-1 and subsequent plasma cell differentiation. Sci Signal. 2011;4:25-8. https://doi. org/10.1126/scisignal.2001592.

46. Morgan MA, Magnusdottir E, Kuo TC, et al. Blimp-1/Prdm1 alternative promoter usage during mouse development and plasma cell differentiation. Mol Cell Biol. 2009;29:5813-27. https://doi.org/10.1128/ mcb.00670-09.

47. Klein U, Casola S, Cattoretti G, et al. Transcription factor IRF4 controls plasma cell differentiation and class-switch recombination. Nat Immunol. 2006;7:773-82. https://doi.org/10.1038/ni1357.

48. Mittrucker HW, Matsuyama T, Grossman A, et al. Requirement for the transcription factor LSIRF/IRF4 for mature B and T lymphocyte function. Science. 1997;275:540-3.

49. Sciammas R, Shaffer AL, Schatz JH, Zhao H, Staudt LM, Singh H. Graded expression of interferon regulatory factor-4 coordinates isotype switching with plasma cell differentiation. Immunity. 2006;25:225-36. https:// doi.org/10.1016/j.immuni.2006.07.009.

50. Calfon $\mathrm{M}$, Zeng $\mathrm{H}$, Urano $\mathrm{F}$, et al. IRE1 couples endoplasmic reticulum load to secretory capacity by processing the XBP-1 mRNA. Nature. 2002;415:92-6. https://doi.org/10.1038/415092a.

51. Ron D, Walter P. Signal integration in the endoplasmic reticulum unfolded protein response. Nat Rev Mol Cell Biol. 2007;8:519-29. https ://doi.org/10.1038/nrm2199.

52. Masciarelli SF, Fra AM, Pengo N, Bertolotti M, Cenci S, Fagioli C, Ron D, Hendershot LM, Sitia R. CHOP-independent apoptosis and pathwayselective induction of the UPR in developing plasma cells. Mol Immunol. 2010:47:56-65. https://doi.org/10.1016/j.molimm.

53. Shaffer AL, Shapiro-Shelef M, Iwakoshi NN, et al. XBP1, downstream of Blimp-1, expands the secretory apparatus and other organelles, and increases protein synthesis in plasma cell differentiation. Immunity. 2004:21:81-93. https://doi.org/10.1016/j.immuni.2004.06.010.

54. Tirosh B, Iwakoshi NN, Glimcher LH, Ploegh HL. XBP-1 specifically promotes IgM synthesis and secretion, but is dispensable for degradation of glycoproteins in primary B cells. J Exp Med. 2005;202:505-16. https:// doi.org/10.1084/jem.20050575.

55. Misiewicz M, Dery MA, Foveau B, Jodoin J, Ruths D, LeBlanc AC. Identification of a novel endoplasmic reticulum stress response element regulated by XBP1. J Biol Chem. 2013;288:20378-91. https://doi. org/10.1074/jbc.M113.457242.

56. Kim SJ, Caton M, Wang C, Khalil M, Zhou ZJ, Hardin J, Diamond B. Increased IL-12 inhibits B cells' differentiation to germinal center cells and promotes differentiation to short-lived plasmablasts. J Exp Med. 2007;205:2437-48

57. Metzger DW, McNutt RM, Collins JT, Buchanan JM, Van Cleave VH, Dunnick WA. Interleukin-12 acts as an adjuvant for humoral immunity through interferon-gamma-dependent and -independent mechanisms. Eur J Immunol. 1997;27:1958-65. https://doi.org/10.1002/ eji.1830270820.

58. Dubois B, Bridon JM, Fayette J, et al. Dendritic cells directly modulate B cell growth and differentiation. J Leukoc Biol. 1999;66:224-30.

59. Dubois $B$, Massacrier C, Vanbervliet $B$, et al. Critical role of IL-12 in dendritic cell-induced differentiation of naive B lymphocytes. J Immunol. 1998;161:2223-31.

60. Hargreaves DC, Hyman PL, Lu TT, et al. A coordinated change in chemokine responsiveness guides plasma cell movements. J Exp Med. 2001:194:45-56.

61. Hauser AE, Debes GF, Arce S, et al. Chemotactic responsiveness toward ligands for CXCR3 and CXCR4 is regulated on plasma blasts during the time course of a memory immune response. J Immunol. 2002;169:1277-82.

62. Bowman EP, Kuklin NA, Youngman KR, et al. The intestinal chemokine thymus-expressed chemokine (CCL25) attracts IgA antibody-secreting cells. J Exp Med. 2002;195:269-75.

63. Ansel KM, Cyster JG. Chemokines in lymphopoiesis and lymphoid organ development. Curr Opin Immunol. 2001;13:172-9. 
64. Arai F, Hirao A, Ohmura M, et al. Tie2/angiopoietin-1 signaling regulates hematopoietic stem cell quiescence in the bone marrow niche. Cell. 2004;118:149-61. https://doi.org/10.1016/j.cell.2004.07.004.

65. Zhang J, Niu C, Ye L, et al. Identification of the haematopoietic stem cell niche and control of the niche size. Nature. 2003:425:836-41. https:// doi.org/10.1038/nature02041.

66. Kiel MJ, Morrison SJ. Maintaining hematopoietic stem cells in the vascular niche. Immunity. 2006;25:862-4. https://doi.org/10.1016/j.immun i.2006.11.005.

67. Kopp HG, Avecilla ST, Hooper AT, Rafii S. The bone marrow vascular niche: home of HSC differentiation and mobilization. Physiology. 2005;20:349-56. https://doi.org/10.1152/physiol.00025.2005.

68. Suda T, Arai F, Hirao A. Hematopoietic stem cells and their niche. Trends Immunol. 2005;8:426-33.

69. Sugiyama T, Kohara H, Noda M, Nagasawa T. Maintenance of the hematopoietic stem cell pool by CXCL12-CXCR4 chemokine signaling in bone marrow stromal cell niches. Immunity. 2006;25:977-88. https://doi. org/10.1016/j.immuni.2006.10.016.

70. Calvi LM, Adams GB, Weibrecht KW, et al. Osteoblastic cells regulate the haematopoietic stem cell niche. Nature. 2003;425:841-6. https://doi. org/10.1038/nature02040.

71. Manz RA, Radbruch A. Plasma cells for a lifetime? Eur J Immunol. 2002:32:923-7.

72. Manz RA, Thiel A, Radbruch A. Lifetime of plasma cells in the bone marrow. Nature. 1997;388:133-4. https://doi.org/10.1038/40540.

73. Manz RA, Lohning M, Cassese G, Thiel A, Radbruch A. Survival of long-lived plasma cells is independent of antigen. Int Immunol. 1998;10:1703-11.

74. Tew JG, DiLosa RM, Burton GF, et al. Germinal centers and antibody production in bone marrow. Immunol Rev. 1992;126:99-112.

75. Cassese G, Lindenau S, de Boer B, et al. Inflamed kidneys of NZB/W mice are a major site for the homeostasis of plasma cells. Eur J Immunol. 2001;31:2726-32.

76. Sze DM, Toellner KM, Garcia DVC, Taylor DR, MacLennan IC. Intrinsic constraint on plasmablast growth and extrinsic limits of plasma cell survival. J Exp Med. 2000;192:813-21.

77. Slifka MK, Antia R, Whitmire JK, Ahmed R. Humoral immunity due to long-lived plasma cells. Immunity. 1998:8:363-72.

78. Hammarlund E, Lewis MW, Hansen SG, et al. Duration of antiviral immunity after smallpox vaccination. Nat Med. 2003;9:1131-7. https:// doi.org/10.1038/nm917.

79. Benner R, Hijmans W, Haaijman JJ. The bone marrow: the major source of serum immunoglobulins, but still a neglected site of antibody formation. Clin Exp Immunol. 1981;46:1-8.

80. Morell A, Terry WD, Waldmann TA. Metabolic properties of IgG subclasses in man. J Clin Invest. 1970;49:673-80. https://doi.org/10.1172/ jci106279.

81. Vieira P, Rajewsky K. The half-lives of serum immunoglobulins in adult mice. Eur J Immunol. 1988;18:313-6. https://doi.org/10.1002/eji.18301 80221.

82. Fahey $\mathrm{J}$, Sell S. The immunoglobulins of mice and the metabolis(catabolic) properties of five immunoglobulin classes. J Exp Med. 1965:122:41-58

83. Bonnaure G, Gervais-St-Amour C, Neron S. Bone marrow mesenchymal stem cells enhance the differentiation of human switched memory $B$ lymphocytes into plasma cells in serum-free medium. J Immunol Res. 2016:2016:780-1. https://doi.org/10.1155/2016/7801781.

84. Roldan E, Garcia-Pardo A, Brieva JA. VLA-4-fibronectin interaction is required for the terminal differentiation of human bone marrow cells capable of spontaneous and high rate immunoglobulin secretion. J Exp Med. 1992;175:1739-47

85. Tabera S, Perez-Simon JA, Diez-Campelo M, et al. The effect of mesenchymal stem cells on the viability, proliferation and differentiation of B-lymphocytes. Haematologica. 2008;93:1301-9. https://doi. org/10.3324/haematol.12857.

86. Dallos T, Krivosikova M, Chorazy-Massalska M, et al. BAFF from bone marrow-derived mesenchymal stromal cells of rheumatoid arthritis patients improves their B-cell viability-supporting properties. Folia Bio (Praha). 2009:55:166-76.
87. Gupta D, Treon SP, Shima Y, et al. Adherence of multiple myeloma cells to bone marrow stromal cells upregulates vascular endothelial growth factor secretion: therapeutic applications. Leukemia. 2001;15:1950-61.

88. Kumar S, Witzig TE, Timm M, et al. Bone marrow angiogenic ability and expression of angiogenic cytokines in myeloma: evidence favoring loss of marrow angiogenesis inhibitory activity with disease progression. Blood. 2004:104:1159-65. https://doi.org/10.1182/blood-2003-11-3811.

89. Chauhan D, Uchiyama H, Akbarali Y, et al. Multiple myeloma cell adhesion-induced interleukin-6 expression in bone marrow stromal cells involves activation of NF-kappa B. Blood. 1996;87:1104-12.

90. Rodriguez GM, Talke Y, Goebel N, Hermann F, Reich B, Mack M. Basophils support the survival of plasma cells in mice. J Immunol. 2010;185:71805. https://doi.org/10.4049/jimmunol.1002319.

91. Chu VT, Berek C. Immunization induces activation of bone marrow eosinophils required for plasma cell survival. Eur J Immunol. 2012:42:130-7. https://doi.org/10.1002/eji.201141953.

92. Winter O, Moser K, Mohr E, et al. Megakaryocytes constitute a functional component of a plasma cell niche in the bone marrow. Blood. 2010;116:1867-75. https://doi.org/10.1182/blood-2009-12-259457.

93. Rozanski $\mathrm{CH}$, Arens $\mathrm{R}$, Carlson LM, et al. Sustained antibody responses depend on CD28 function in bone marrow-resident plasma cells. J Exp Med. 2011;208:1435-46. https://doi.org/10.1084/jem.20110040.

94. Chevrier S, Genton C, Kallies A, et al. CD93 is required for maintenance of antibody secretion and persistence of plasma cells in the bone marrow niche. Proc Natl Acad Sci USA. 2009;106:3895-900. https://doi. org/10.1073/pnas.0809736106.

95. Wang J, Hendrix A, Hernot S, et al. Bone marrow stromal cell-derived exosomes as communicators in drug resistance in multiple myeloma cells. Blood. 2014;124:555-66. https://doi.org/10.1182/blood-2014-03562439.

96. Shirakawa R, Horiuchi H. Ral GTPases: crucial mediators of exocytosis and tumourigenesis. J Biochem. 2015;157:285-99. https://doi. org/10.1093/jb/mvv029.

97. Hoyer BF, Moser K, Hauser AE, et al. Short-lived plasmablasts and long-lived plasma cells contribute to chronic humoral autoimmunity in NZB/W mice. J Exp Med. 2004;199:1577-84. https://doi.org/10.1084/ jem.20040168.

98. Neubert K, Meister S, Moser K, et al. The proteasome inhibitor bortezomib depletes plasma cells and protects mice with lupus-like disease from nephritis. Nat Med. 2008;14:748-55. https://doi.org/10.1038/ $\mathrm{nm} 1763$.

99. Tonegawa S. Somatic generation of antibody diversity. Nature. 1983;302:575-81

100. Meffre E, Casellas R, Nussenzweig MC. Antibody regulation of B cell development. Nat Immunol. 2000;1:379-85.

101. Vos Q, Lees A, Wu ZQ, Snapper CM, Mond JJ. B-cell activation by T-cell-independent type 2 antigens as an integral part of the humoral immune response to pathogenic microorganisms. Immunol Rev. 2000:176:154-70.

102. Heyman B. Regulation of antibody responses via antibodies, complement, and Fc receptors. Annu Rev Immunol. 2000;18:709-37. https:// doi.org/10.1146/annurev.immunol.18.1.709.

103. Maizels N. Immunoglobulin gene diversification. Annu Rev Genet. 2005;39:23-46.

104. Rogozin IB, Kolchanov NA. Somatic hypermutagenesis in immunoglobulin genes II Influence of neighbouring base sequences on mutagenesis. Biochim Biophys Acta. 1992;117:11-8.

105. Kinoshita K, Honjo T. Linking class-switch recombination with somatic hypermutation. Nat Rev Mol Cell Biol. 2001;2:493-503. https://doi. org/10.1038/35080033

106. Fazilleau N, Mark L, McHeyzer-Williams LJ, McHeyzer-Williams MG. Follicular helper T cells: lineage and location. Immunity. 2009;30:324-35. https://doi.org/10.1016/j.immuni.2009.03.003.

107. King C, Tangye SG, Mackay CR. T follicular helper (TFH) cells in normal and dysregulated immune responses. Annu Rev Immunol. 2008;26:741-66. https://doi.org/10.1146/annurev.immunol.26.02160 7.090344

108. Vinuesa CG, Sanz I, Cook MC. Dysregulation of germinal centres in autoimmune disease. Nat Rev Immunol. 2009;9:845-57. https://doi. org/10.1038/nri2637. 
109. Ansel KM, McHeyzer-Williams LJ, Ngo VN, McHeyzer-Williams MG, Cyster JG. In vivo-activated CD4 T cells upregulate CXC chemokine receptor 5 and reprogram their response to lymphoid chemokines. J Exp Med. 1999;190:1123-34.

110. Fazilleau N, Eisenbraun MD, Malherbe L, et al. Lymphoid reservoirs of antigen-specific memory Thelper cells. Nat Immunol. 2007:8:753-61. https://doi.org/10.1038/ni1472.

111. Fazilleau N, McHeyzer-Williams LJ, Rosen H, McHeyzer-Williams MG. The function of follicular helper T cells is regulated by the strength of T cell antigen receptor binding. Nat Immunol. 2009;10:375-84. https://doi. org/10.1038/ni.1704.

112. Vinuesa CG, Tangye SG, Moser B, Mackay CR. Follicular B helper T cells in antibody responses and autoimmunity. Nat Rev Immunol. 2005;5:85365. https://doi.org/10.1038/nri1714.

113. Linterman MA, Beaton L, Yu D, et al. IL-21 acts directly on B cells to regulate $\mathrm{BCl}-6$ expression and germinal center responses. J Exp Med. 2010;207:353-63. https://doi.org/10.1084/jem.20091738.

114. Zotos D, Coquet JM, Zhang Y, et al. IL-21 regulates germinal center B cell differentiation and proliferation through a B cell-intrinsic mechanism. J Exp Med. 2010;207:365-78. https://doi.org/10.1084/jem.20091777.

115. Poholek AC, Hansen K, Hernandez SG, et al. In vivo regulation of Bcl6 and T follicular helper cell development. J Immunol. 2010;185:313-26. https://doi.org/10.4049/jimmunol.0904023.

116. Good-Jacobson KL, Szumilas CG, Chen L, Sharpe AH, Tomayko MM, Shlomchik MJ. PD-1 regulates germinal center B cell survival and the formation and affinity of long-lived plasma cells. Nat Immunol. 2010;11:535-42. https://doi.org/10.1038/ni.1877.

117. McHeyzer-Williams $L$, McHeyzer-Williams MG. Antigenspecific memory B cell development. Annu Rev Immunol. 2005;23:487-513.

118. Pelletier N, McHeyzer-Williams LJ, Wong KA, Urich E, Fazilleau N, McHeyzer-Williams MG. Plasma cells negatively regulate the follicular helper T cell program. Nat Immunol. 2010;11:1110-8. https://doi. org/10.1038/ni.1954.

119. Shapiro-Shelef M, Lin Kl, McHeyzer-Williams LJ, Liao J, McHeyzerWilliams MG, Calame K. Blimp-1 is required for the formation of immunoglobulin secreting plasma cells and pre-plasma memory B cells. Immunity. 2003;19:607-20.

120. Jang E, Cho WS, Cho ML, et al. Foxp3+ regulatory T cells control humoral autoimmunity by suppressing the development of long-lived plasma cells. J Immunol. 2011;186:1546-53. https://doi.org/10.4049/ jimmunol.1002942.

121. Jang E, Cho WS, Oh YK, et al. Splenic long-lived plasma cells promote the development of follicular helper T cells during autoimmune responses. J Immunol. 2016;196:1026-35. https://doi.org/10.4049/ jimmunol.1401059.

122. Ballesteros-Tato A, Leon B, Graf BA, et al. Interleukin-2 inhibits germinal center formation by limiting $T$ follicular helper cell differentiation. Immunity. 2012;36:847-56. https://doi.org/10.1016/j.immun i.2012.02.012.

123. Johnston RJ, Choi YS, Diamond JA, Yang JA, Crotty S. STAT5 is a potent negative regulator of TFH cell differentiation. J Exp Med. 2012;209:24350. https://doi.org/10.1084/jem.20111174.

124. Nurieva RI, Podd A, Chen Y, et al. STAT5 protein negatively regulates T follicular helper (Tfh) cell generation and function. J Biol Chem. 2012;287:11234-9. https://doi.org/10.1074/jbc.M111.324046.

125. Kato H, Kato R, Fujihashi K, McGhee JR. Role of mucosal antibodies in viral infections. Curr Top Microbiol Immunol. 2001;260:201-28.

126. Honda K, Littman DR. The microbiota in adaptive immune homeostasis and disease. Nature. 2016;535:75-84. https://doi.org/10.1038/natur e18848.

127. Macpherson AJ, Uhr T. Induction of protective IgA by intestinal dendritic cells carrying commensal bacteria. Science. 2004;303:1662-5. https://doi.org/10.1126/science.1091334.

128. Slack E, Hapfelmeier S, Stecher B, et al. Innate and adaptive immunity cooperate flexibly to maintain host-microbiota mutualism. Science. 2009:325:617-20. https://doi.org/10.1126/science.1172747.

129. Yuki Y, Kiyono H. New generation of mucosal adjuvants for the induction of protective immunity. Rev Med Virol. 2003;13:293-310.

130. Kagnoff MF. Immunology of the intestinal tract. Gastroenterology. 1993;105:1275-80.
131. Fagarasan S, Kinoshita K, Muramatsu M, Ikuta K, Honjo T. In situ class switching and differentiation to $\lg A$-producing cells in the gut lamina propria. Nature. 2001;413:639-43. https://doi.org/10.1038/35098100.

132. Schroten H, Bosch M, Nobis-Bosch R, Kohler H, Hanisch FG, Plogmann R. Secretory immunoglobulin $A$ is a component of the human milk fat globule membrane. Pediatr Res. 1999;45:82-6. https://doi. org/10.1203/00006450-199901000-00014.

133. Hieshima K, Kawasaki Y, Hanamoto H, et al. CC chemokine ligands 25 and 28 play essential roles in intestinal extravasation of IgA antibodysecreting cells. J Immunol. 2004;173:3668-75.

134. Zabel BA, Agace WW, Campbell JJ, et al. Human G protein-coupled receptor GPR-9-6/CC chemokine receptor 9 is selectively expressed on intestinal homing T lymphocytes, mucosal lymphocytes, and thymocytes and is required for thymus-expressed chemokine-mediated chemotaxis. J Exp Med. 1999;190:1241-56.

135. Johansson-Lindbom B, Svensson M, Wurbel MA, Malissen B, Marquez $G$, Agace W. Selective generation of gut tropic T cells in gut-associated lymphoid tissue (GALT): requirement for GALT dendritic cells and adjuvant. J Exp Med. 2003;198:963-9. https://doi.org/10.1084/jem.20031 244.

136. Kunkel EJ, Campbell JJ, Haraldsen G, et al. Lymphocyte CC chemokine receptor 9 and epithelial thymus-expressed chemokine (TECK) expression distinguish the small intestinal immune compartment: epithelial expression of tissue-specific chemokines as an organizing principle in regional immunity. J Exp Med. 2000;192:761-8.

137. Papadakis KA, Prehn J, Nelson V, et al. The role of thymus-expressed chemokine and its receptor CCR9 on lymphocytes in the regional specialization of the mucosal immune system. J Immunol. 2000;165:5069-76.

138. Round JL, Mazmanian SK. The gut microbiota shapes intestinal immune responses during health and disease. Nat Rev Immunol. 2009;9:313-23. https://doi.org/10.1038/nri2515.

139. Suzuki K, Ha SA, Tsuji M, Fagarasan S. Intestinal IgA synthesis: a primitive form of adaptive immunity that regulates microbial communities in the gut. Semin Immunol. 2007;19:127-35. https://doi.org/10.1016/j. smim.2006.10.001.

140. Turnbaugh PJ, Ley RE, Hamady M, Fraser-Liggett CM, Knight R, Gordon JI. The human microbiome project. Nature. 2007:449:804-10. https:// doi.org/10.1038/nature06244.

141. Helander A, Miller CL, Myers KS, Neutra MR, Nibert ML. Protective immunoglobulin $A$ and $G$ antibodies bind to overlapping intersubunit epitopes in the head domain of type 1 reovirus adhesin sigma1. J Virol. 2004;78:10695-705. https://doi.org/10.1128/jvi.78.19.10695-10705 2004.

142. Peterson DA, McNulty NP, Guruge JL, Gordon Jl. IgA response to symbiotic bacteria as a mediator of gut homeostasis. Cell Host Microbe. 2007;2:328-39. https://doi.org/10.1016/j.chom.2007.09.013.

143. Fagarasan S, Muramatsu M, Suzuki K, Nagaoka H, Hiai H, Honjo T. Critical roles of activation-induced cytidine deaminase in the homeostasis of gut flora. Science. 2002;298:1424-7. https://doi.org/10.1126/scien ce.1077336.

144. Kubinak JL, Round JL. Do antibodies select a healthy microbiota? Nat Rev Immunol. 2016;16:767-74. https://doi.org/10.1038/nri.2016.114.

145. Kawamoto S, Maruya M, Kato LM, et al. Foxp3(+) T cells regulate immunoglobulin a selection and facilitate diversification of bacterial species responsible for immune homeostasis. Immunity. 2014;41:152-65. https ://doi.org/10.1016/j.immuni.2014.05.016.

146. Kawamoto S, Tran TH, Maruya M, et al. The inhibitory receptor PD-1 regulates $\lg \mathrm{A}$ selection and bacterial composition in the gut. Science. 2012;336:485-9. https://doi.org/10.1126/science.1217718.

147. Quan CP, Berneman A, Pires R, Avrameas S, Bouvet JP. Natural polyreactive secretory immunoglobulin A autoantibodies as a possible barrier to infection in humans. Infect Immun. 1997;65:3997-4004.

148. Fransen F, Zagato E, Mazzini E, et al. BALB/C and C57BL/6 mice differ in polyreactive IgA abundance, which impacts the generation of antigenspecific IgA and microbiota diversity. Immunity. 2015;43:527-40. https ://doi.org/10.1016/j.immuni.2015.08.011.

149. Wijburg OL, Uren TK, Simpfendorfer K, Johansen FE, Brandtzaeg P, Strugnell RA. Innate secretory antibodies protect against natural Salmonella typhimurium infection. J Exp Med. 2006;203:21-6. https://doi. org/10.1084/jem.20052093. 
150. Loman S, Jansen HM, Out TA, Lutter R. Interleukin-4 and interferongamma synergistically increase secretory component gene expression, but are additive in stimulating secretory immunoglobulin A release by Calu-3 airway epithelial cells. Immunology. 1999;96:537-43.

151. Hiroi T, Yanagita M, lijima H, et al. Deficiency of IL-5 receptor alphachain selectively influences the development of the common mucosal immune system independent IgA-producing B-1 cell in mucosa-associated tissues. J Immunol. 1999;162:821-8.

152. Bromander AK, Ekman L, Kopf M, Nedrud JG, Lycke NY. IL-6 deficient mice exhibit normal mucosal Ig A responses to local immunizations and helicobacter felis infection. J Immunol. 1996;150:4290.

153. Fukushima Y, Kawata Y, Hara H, Terada A, Mitsuoka T. Effect of a probiotic formula on intestinal immunoglobulin A production in healthy children. Int J Food Microbiol. 1998;42:39-44.

154. Kaila M, Isolauri E, Soppi E, Virtanen E, Laine S, Arvilommi H. Enhancement of the circulating antibody secreting cell response in human diarrhea by a human Lactobacillus strain. Pediatr Res. 1992;32:141-4. https://doi.org/10.1203/00006450-199208000-00002.

155. He B, Xu W, Santini PA, et al. Intestinal bacteria trigger T cell-independent immunoglobulin $A(2)$ class switching by inducing epithelial-cell secretion of the cytokine APRIL. Immunity. 2007;26:812-26. https://doi. org/10.1016/j.immuni.2007.04.014.

156. Shang $L$, Fukata $M$, Thirunarayanan $N$, et al. Toll-like receptor signaling in small intestinal epithelium promotes B-cell recruitment and IgA production in lamina propria. Gastroenterology. 2008;135:529-38. https://doi. org/10.1053/j.gastro.2008.04.020.

157. de Souza HSP, Fiocchi C, lliopoulos D. The IBD interactome: an integrated view of aetiology, pathogenesis and therapy. Nat Rev Gastroenterol Hepatol. 2017;14(12):739.

158. Schmidt C, Stallmach A. Etiology and pathogenesis of inflammatory bowel disease. Minerva Gastroenterol Dietol. 2005;51:127-45.

159. Dignass A, Eliakim R, Magro F, et al. Second European evidence-based consensus on the diagnosis and management of ulcerative colitis Part 1: definitions and diagnosis (Spanish version). Rev Gastroenterol Mex. 2014;79:263-89. https://doi.org/10.1016/.jrgmx.2014.10.001.

160. Maecker HT, McCoy JP, Nussenblatt R. Standardizing immunophenotyping for the human immunology project. Nat Rev Immunol. 2012;12:191-200. https://doi.org/10.1038/nri3158.

161. Jinno Y, Ohtani H, Nakamura S, et al. Infiltration of CD19+ plasma cells with frequent labeling of Ki-67 in corticosteroid-resistant active ulcerative colitis. Virchows Arch. 2006;448:412-21. https://doi.org/10.1007/s0042 8-005-0136-7.

162. Hosomi S, Oshitani N, Kamata N, et al. Increased numbers of immature plasma cells in peripheral blood specifically overexpress chemokine receptor CXCR3 and CXCR4 in patients with ulcerative colitis. Clin Exp Immunol. 2011;163:215-24. https://doi.org/10.111 1/j.1365-2249.2010.04290.

163. Tarlton NJ, Green CM, Lazarus NH, et al. Plasmablast frequency and trafficking receptor expression are altered in pediatric ulcerative colitis. Inflamm Bowel Dis. 2012;18:2381-91. https://doi.org/10.1002/ibd.22962.

164. MacDermott RP, Nash GS, Bertovich MJ, Seiden MV, Bragdon MJ, Beale MG. Alterations of IgM, IgG, and IgA Synthesis and secretion by peripheral blood and intestinal mononuclear cells from patients with ulcerative colitis and Crohn's disease. Gastroenterology. 1981;81:844-52.

165. Brandtzaeg P, Johansen FE. Mucosal B cells: phenotypic characteristics, transcriptional regulation, and homing properties. Immunol Rev. 2005;206:3263. https://doi.org/10.1111/j.0105-2896.2005.00283.x

166. Wang $X$, Jiang $Y$, Zhu $Y$, et al. Circulating memory $B$ cells and plasmablasts are associated with the levels of serum immunoglobulin in patients with ulcerative colitis. J Cell Mol Med. 2016;20:804-14. https://doi.org/10.1111/ jcmm.12728.

167. Uo M, Hisamatsu T, Miyoshi J, et al. Mucosal CXCR4+ lgG plasma cells contribute to the pathogenesis of human ulcerative colitis through FcgammaR-mediated CD14 macrophage activation. Gut. 2013;62:173444. https://doi.org/10.1136/gutjnl-2012-303063.

168. Wang Z, Zhu M, Luo C, et al. High level of IgG4 as a biomarker for a new subset of inflammatory bowel disease. Sci Rep. 2018;8:100-18. https://doi. org/10.1038/s41598-018-28397-8.

169. Probert CS, Jayanthi V, Pinder D, Wicks AC, Mayberry JF. Epidemiological study of ulcerative proctocolitis in Indian migrants and the indigenous population of Leicestershire. Gut. 1992;33:687-93.
170. Thia KT, Loftus EV Jr, Sandborn WJ, Yang SK. An update on the epidemiology of inflammatory bowel disease in Asia. Am J Gastroenterol. 2008:103:3167-82.

171. Shaikh SR, Haas KM, Beck MA, Teague H. The effects of diet-induced obesity on B cell function. Clin Exp Immunol. 2015;179:90-9. https://doi. org/10.1111/cei.12444.

172. Conlon M, Bird A. The impact of diet and lifestyle on gut microbiota and human health. Nutrients. 2014;7:17-44.

173. Winer DA, Winer S, Shen L, et al. B cells promote insulin resistance through modulation of T cells and production of pathogenic lgG antibodies. Nat Med. 2011;17:610-7. https://doi.org/10.1038/nm.2353.

174. Marzullo P, Minocci A, Tagliaferri MA, et al. Investigations of thyroid hormones and antibodies in obesity: leptin levels are associated with thyroid autoimmunity independent of bioanthropometric, hormonal, and weight-related determinants. J Clin Endocrinol Metab. 2010;95:3965-72. https://doi. org/10.1210/jc.2009-2798.

175. Rosenbloom AL. Obesity, insulin resistance, beta-cell autoimmunity, and the changing clinical epidemiology of childhood diabetes. Diabetes Care. 2003;26:2954-6.

176. Arai S, Maehara N, Iwamura Y, et al. Obesity-associated autoantibody production requires AIM to retain the immunoglobulin M immune complex on follicular dendritic cells. Cell Rep. 2013;3:1187-98. https://doi. org/10.1016/j.celrep.2013.03.006.

177. Lilja M, Raisanen S, Stenfors LE. Immunoglobulin- and complementcoated bacteria in pus from peritonsillar abscesses. J Laryngol Otol. 1998;112:634-8.

178. Telemo E, Korotkova M, Hanson LA. Antigen presentation and processing in the intestinal mucosa and lymphocyte homing. Ann Allergy Asthma Immunol. 2003;90:28-33.

179. Thang CL, Boye Jl, Zhao X. Low doses of allergen and probiotic supplementation separately or in combination alleviate allergic reactions to cow beta-lactoglobulin in mice. J Nutr. 2013;143:136-41. https://doi. org/10.3945/jn.112.169466.

180. Galli SJ, Tsai M. IgE and mast cells in allergic disease. Nat Med. 2012;18:693704. https://doi.org/10.1038/nm.2755.

181. Burton OT, Oettgen HC. Beyond immediate hypersensitivity: evolving roles for lgE antibodies in immune homeostasis and allergic diseases. Immunol Rev. 2011;242:128-43. https://doi.org/10.1111/j.1600-065X.2011.01024.x.

182. Berntsson J, Nodin B, Eberhard J, Micke P, Jirstrom K. Prognostic impact of tumour-infiltrating B cells and plasma cells in colorectal cancer. Int J Cancer. 2016;139:1129-39. https://doi.org/10.1002/ijc.30138.

183. StaffC, Magnusson CG, Hojjat-Farsangi M, et al. Induction of IgM, IgA and lgE antibodies in colorectal cancer patients vaccinated with a recombinant CEA protein. J Clin Immunol. 2012;32:855-65. https://doi.org/10.1007/ s10875-012-9662-7.

184. Valerius T, Stockmeyer B, van Spriel AB, et al. FcalphaRI (CD89) as a novel trigger molecule for bispecific antibody therapy. Blood. 1997;90:4485-92.

185. Huls G, Heijnen IA, Cuomo E, et al. Antitumor immune effector mechanisms recruited by phage display-derived fully human $\lg \mathrm{G} 1$ and $\lg A 1$ monoclonal antibodies. Cancer Res. 1999;59:5778-84.

186. Lohse S, Derer S, Beyer T, et al. Recombinant dimeric IgA antibodies against the epidermal growth factor receptor mediate effective tumor cell killing. J Immunol. 2011;186:3770-8. https://doi.org/10.4049/jimmunol.1003082.

187. Quiding-Jarbrink M, Nordstrom I, Granstrom G, et al. Differential expression of tissue-specific adhesion molecules on human circulating antibodyforming cells after systemic, enteric, and nasal immunizations. A molecular basis for the compartmentalization of effector B cell responses. J Clin Invest. 1997;99:1281-6. https://doi.org/10.1172/jci1 19286.

188. Kunkel EJ, Kim CH, Lazarus NH, et al. CCR10 expression is a common feature of circulating and mucosal epithelial tissue IgA Ab-secreting cells. J Clin Invest. 2003;111:1001-10. https://doi.org/10.1172/jci17244.

189. Lazarus NH, Kunkel EJ, Johnston B, Wilson E, Youngman KR, Butcher EC. A common mucosal chemokine (mucosae-associated epithelial chemokine/CCL28) selectively attracts IgA plasmablasts. J Immunol. 2003;170:3799-805.

190. Sundstrom P, Lundin SB, Nilsson LA, Quiding-Jarbrink M. Human IgA-secreting cells induced by intestinal, but not systemic, immunization respond to CCL25 (TECK) and CCL28 (MEC). Eur J Immunol. 2008;38:3327-38. https:// doi.org/10.1002/eji.200838506. 
191. Muthuswamy RV, Sundström P, Börjesson L, Gustavsson B, Quiding-Järbrink M. Impaired migration of IgA-secreting cells to colon adenocarcinomas. Cancer Immunol Immunother. 2013;62(6):989-97.

192. Svensson H, Olofsson V, Lundin S, et al. Accumulation of CCR4(+)CTLA-4 FOXP3(+)CD25(hi) regulatory T cells in colon adenocarcinomas correlate to reduced activation of conventional T cells. PLoS ONE. 2012;7:306-15. https://doi.org/10.1371/journal.pone.0030695.

193. Dimberg J, Hugander A, Wagsater D. Protein expression of the chemokine, CCL28, in human colorectal cancer. Int J Oncol. 2006;28:315-9.

194. Le Gouvello S, Bastuji-Garin S, Aloulou N, et al. High prevalence of Foxp3 and IL17 in MMR-proficient colorectal carcinomas. Gut. 2008;57:772-9. https:// doi.org/10.1136/gut.2007.123794.
195. Tosolini M, Kirilovsky A, Mlecnik B, et al. Clinical impact of different classes of infiltrating $T$ cytotoxic and helper cells (Th1, th2, treg, th17) in patients with colorectal cancer. Cancer Res. 2011;71:1263-71. https://doi. org/10.1158/0008-5472.CAN-10-2907.

196. Stamenkovic I, Yu Q. Merlin, a "magic" linker between extracellular cues and intracellular signaling pathways that regulate cell motility, proliferation, and survival. Curr Protein Pept Sci. 2010;11:471-84.
Ready to submit your research? Choose BMC and benefit from:

- fast, convenient online submission

- thorough peer review by experienced researchers in your field

- rapid publication on acceptance

- support for research data, including large and complex data types

- gold Open Access which fosters wider collaboration and increased citations

- maximum visibility for your research: over 100M website views per year

At BMC, research is always in progress.

Learn more biomedcentral.com/submissions 